\title{
Seeding Social Capital? Urban Community Gardening and Social Capital
}

\author{
Søren Christensen \\ Center for Nutrition and Rehabilitation, University College Zealand, Denmark
}

Copyright $\bigcirc 2017$ by authors, all rights reserved. Authors agree that this article remains permanently open access under the terms of the Creative Commons Attribution License 4.0 International License

\begin{abstract}
There is a continuing debate regarding urban community gardening's benefits to local communities, and a particularly interesting branch of this debate has focused on community gardens capacity to encourage and facilitate social interaction, which may generate social capital. Social capital is an increasingly important concept in international research and measures of social capital have been associated with various measures of health. In a meta-analysis of literature published between 2000 and 2016 regarding community gardens' social advantages, through the lens of the concept of social capital, it is demonstrated that several studies substantiate that urban community gardens create social capital, both bonding and bridging, and exhibit indications of linking. It is moreover identified how there is much to be learned from future research, illuminating how urban community gardens can foster social capital, and thus benefit cities and local communities. The meta-analysis finds that mixed methods approaches can enrich future research on how urban community gardens can foster social capital, and thus benefit cities and local communities. Particular promising would be using qualitative methods that focus on the meanings ascribed to urban garden's activities in combination with documenting the sociodemographic, ethnic, and cultural composition of the volunteers and gardeners, in comparison with the local neighborhood in general. The analysis' findings furthermore implicates there is much to be learned from more focus on the structural dimensions of social capital, in addition to the cognitive dimensions, as this would yield a more nuanced depiction of social advantages of urban community gardening.
\end{abstract}

Keywords Urban Community Gardens, Social Capital, Meta-analysis, Health, Inclusion, Neighborhood Development

\section{Introduction}

Urban community gardening, here defined as an activity based in open spaces managed by members of the local community in which foods or flowers are cultivated, has in the last twenty years been widely promoted as a fruitful way to improve both the physical, mental, and social dimensions of health. In particular, there has been extensive research on the potential of urban community gardening for promoting and facilitating social interaction, and the concept of social capital has been used to examine and analyze this [1-4]. This article seeks to critically examine how studies on urban community gardens demonstrate that they function, or can function, as arenas for creating social capital in the peer reviewed literature published on the topic from 2000 to 2016. The myriad of claimed socially desirable outcomes of community gardening are at first glance impressive. These include, among other things, community empowerment and development [5-7], a reduced prevalence of vandalism in local areas [8], [9] social integration [5], [10-13], potential for reducing aggressive behavior in local neighborhoods [14], advancing a sense of community belonging and social networks for residents [15], [16], supporting social interactions across generations and cultural differences [4], [17], [18], greater mutual trust and civic engagement [19], and in a review of a diversity of benefits attributed to community gardens, Draper and Freedman (2010) state that numerous studies show "...positive results in regards to the production of social capital" [20, p. 479].

While social capital in some instances is linked to negative outcomes [21], it is mostly linked to various positive outcomes [22], including improved child development [23], increased mental health [24], lower crime rates [25], [26], reduced mortality [27], lower susceptibility to depression [28] and loneliness [29], higher perceptions of well-being [30], [31] and self-rated health [32], [33]. This supports the importance of examining urban community gardening as arenas for facilitating social capital.

This meta-analysis aims at answering the following two questions:

(1) How is it supported that urban community gardening creates social capital, reviewing the peer reviewed literature published from 2000 to 2016 ? 
(2) What can we learn from existing research on urban community gardens and social capital, reviewing the peer reviewed literature published from 2000 to 2016 ?

\section{Key Concepts and Definitions}

\subsection{Social Capital}

Social Capital is a contested and elusive concept and sociological construct [11]; it means different things to different people, which is revealed in the extensive differences in the usage of the concept [34]. While the earliest specific use of the concept social capital, identified by Woolcock [35], goes back to 1916 and Hanifan, a practical reformer rather than a theorist or sociologist, the term, according to Putnam,"... turns out to have been invented at least six times over the twentieth century, each time to call attention to the ways in which our lives are made more productive by social ties" [36, p. 16]. The concept has captured the attention and application of - and increasingly gaining currency among - social science researchers, policymakers and organizations, with a comprehensive number of publications in recent years, as well as use in education, economics, business and management, epidemiology, health research, leisure studies etc.[34], [35], [37-39]. Although the term has been used from large-scale, macro-level, 'cultural' or 'community' phenomena on the one hand, to small-scale, micro-level intra-family phenomena on the other [34], there are arguably currently three main schools of social capital.

Highly influential Robert Putnam conceives of social capital at the community level, regarding it as a resource, that is, as "...features of social organization, such as networks, norms and social trust that facilitate coordination and cooperation..." [40, p, 67], and distinguish famously between bonding and bridging social capital, one of the most important distinctions in the social capital-theory endeavor to break the concept into different sub-types [34, p. 19]. Broadly speaking, bonding social capital refers to connections between like-minded people, homogenous groups and strong ties, whereas bridging social capital refers to links between heterogeneous groups - more fragile, but also more inclusive [36], [40], [41]. Woolcock and Szretzer have later added the important idea of 'linking' social capital [35] to Putnam's distinction. Woolcock and Szretzer argued that social relationships that would otherwise be grouped together in the 'bridging' category, functions as an important conceptual refinement, that draws empirical support from a range of studies showing that, especially in poor communities, it is the nature and extent (or lack) of respectful and trusting ties to representatives of formal institutions-e.g. law enforcement officers, social workers, health care providers - that has a major impact on their welfare [35].

Another main school of social capital draws on Pierre Bourdieu, who focus on the resources that accrue to individuals, and define it as " ...the aggregate of the actual or potential resources which is linked to possession of a durable network of more or less institutionalized relationships of mutual acquaintance and recognition" [42, p. 248]. James Coleman's approach to social capital represents a third main school of social capital research, who particularly works in the field of education research. Coleman defines social capital as a variety of entities with two key elements in common that "...consists of some aspect of social structures, and ... facilitate certain actions of actors ... within that structure ... social capital is productive, making possible the achievement of certain ends that in its absence would not be possible" [43, p. 96].

Social capital can thus be both a 'private good' used by its members to achieve gains, as highlighted in the Bourdieu conception) and a 'public good' (shared or group resources constituting a social resource, as emphasized in the Putnam definition), that is, it can be a benefit for communities and/or individuals in that community [36], [44]. Similarly, the distinction between structural social capital and cognitive social capital is regularly highlighted by social capital researchers [36], [45], [46]. Cognitive social capital can be construed as people's perceptions of the level of interpersonal trust as well as norms of reciprocity within the group, while structural social capital, by contrast, is the actual social networks or participation [47, p. 48].

While these are examples of different and contested ways of conceptualizing social capital, this meta-analysis embraces social capital in its multidimensional character, with an overall working definition of social capital as "Social networks and the norms and sanctions that govern their character" [34, p. 4]. More elaborately, I distinguish between bonding, bridging and linking social capital. Following the lines of Putnam [36], [40], [41], Szreter \& Woolcock [22] and Firth et al. [1] bonding social capital is accordingly defined as "trusting and co-operative relations between members of a network who see themselves as being similar, in terms of their shared social identity" [22, p. 654], bridging social capital as more distant ties that "...brings people together from diverse socio-demographic situations..." [1, p. 558], and linking social capital as "norms of respect and networks of trusting relationships between people who are interacting across explicit, formal or institutionalized power or authority gradients in society" [22, p. 655]. Diverse socio-demographic situations are here defined as variables such as age, education, sex, ethnic groups, and class [22], [47]. While the meta-analysis encompasses both 'bonding', 'bridging' and 'linking' social capital, there is a main focus on 'bridging' social capital, as this is more outward looking, inclusive, and incorporating people across different social, ethnic and cultural groups and backgrounds, thereby facilitating the development of broader identities and collectivities, while for instance 'bonding social capital' is more inward looking involving homogeneous groups [36, p. 19]. Despite a tendency to focus either on the individual or collective dimensions of social 
capital [48], the literature on urban community gardening and social capital is evidence of a literature that encompass both, which is in line with Putnam's affirmation that social capital "... can both be simultaneously a "private good" and a "public good"”, [36, p. 20].

\subsection{Urban Community Gardening}

Analyzing urban community gardening through the lens of social capital requires being clear about the specific concept of urban community gardening. However, there is no standardized definition in the academic literature on urban community gardens, and this study confirms Guitart and colleagues' observation that many papers do not define what they mean by the term 'community garden' "...as the concept may seem self-explanatory [17, p. 366]. Reading and analyzing the literature on community gardens and community gardening makes it very clear, this is far from the case. For example, some researchers suggest that urban agriculture is used as a generic term, encompassing both urban community gardening and urban agriculture as acts of cultivation that refer to the same geographical imaginaries [49], [50]. Other authors prefer only to designate professional practices under the umbrella of urban agriculture [49], with an exclusionary focus on urban or metropolitan market-oriented production [51], while other authors in turn employ concepts such as 'organized garden projects' [52] and 'PAC-gardens' ('public access community gardens') as alternative ways of conceptually designate the geographical spaces of community gardens [5]. Thus, scrutinizing the literature on urban community gardening makes it evident that the diversity of what this concept involve, makes it essential to define what is meant by community gardening. Urban community gardening is in this meta-analysis accordingly defined as an activity in "open spaces which are managed and operated by members of the local community in which foods or flowers are cultivated" [4], [12], [52]. The term 'community' in community gardening thus refers to the attribute that they involve convergence of individuals - members of a community - joining together in garden activities open to the public. ${ }^{1}$ This does not necessarily exclude urban agriculture or urban farming, as community gardens in some cases can include plots dedicated to "urban agriculture"" [19], but the focus of this article is urban community gardening and not urban agriculture or city farming per se, unless this is tied to urban community gardening, as defined above. Furthermore, Marion Ernwein has convincingly argued that the term 'urban' poorly reflects the complexity of the representations and practices of urban community gardening

1 The concept of community is of course contested, and interpreted and applied in a multitude of ways in the literature on urban community gardening, and the concept interestingly point to a tension between homogeneity and diversity [89], and it can be argued that the very term 'community' may well constitute the 'locus' of some of the tensions that characterize the literature on urban community gardening. and urban agriculture [49]. As it is not the focus of the present paper to unfold an analysis of the concept 'urban', the present definition of urban is rapportive, that is, if the articles identify the studies as 'urban' (or 'peri-urban'), they are considered urban.

\section{Methodology}

The literature analyzed for this paper was published between 2000 and 2016 and identified searching the bibliographical databases Science Direct, Web of Science, and Cinahl, as well as ProQuest and Google Scholar. Search terms included were 'community gardens' OR 'contested green space' OR 'urban agriculture' OR 'city farms' OR 'shared gardens' OR 'common gardens' OR 'collective gardens' AND 'social capital' OR 'collective efficacy' OR 'social cohesion' OR 'social networks' OR 'neighborhood resources'.1 Boolean operators have thus been used, and references of retrieved articles were examined, identifying further potential relevant studies, as illustrated in the flowchart (table 1).

Table 1. Flow chart

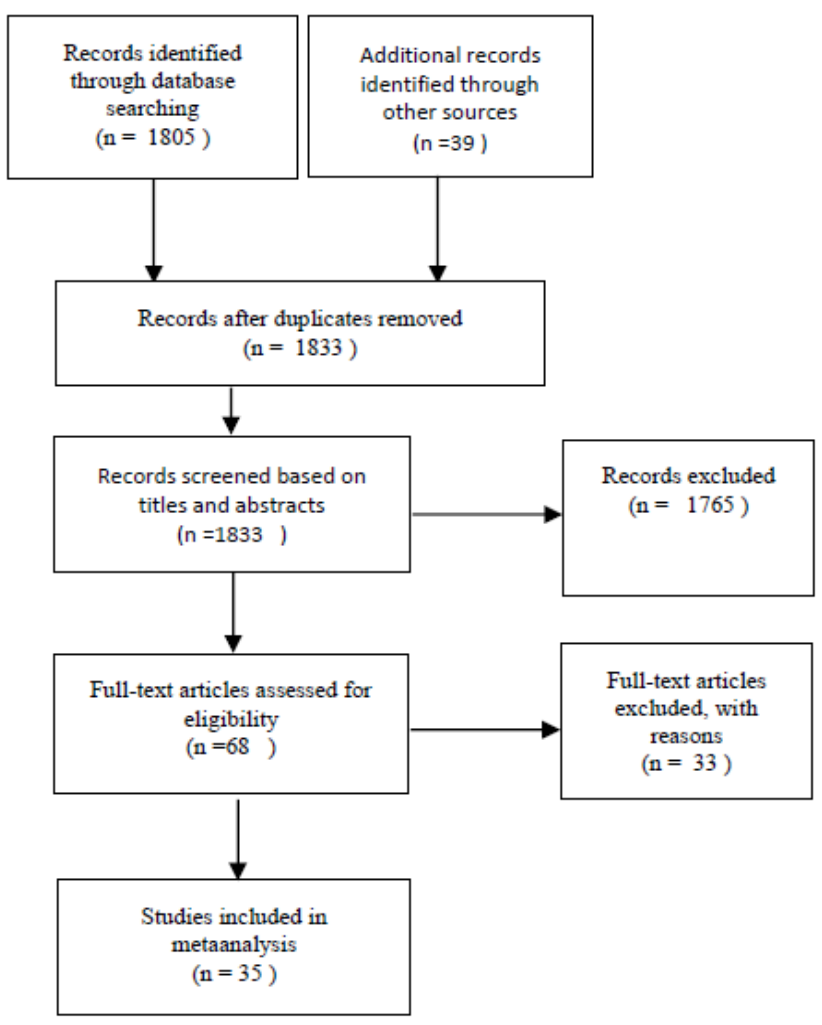

A total of 1844 articles were identified in the original search, which were screened based on titles and abstracts, and 1765 articles were excluded, leaving 68 articles where full texts were read and assessed for eligibility.

The initial substantial number of exclusions were based on whether the abstracts explicitly focused on community gardens (i.e. excluding studies that only focused on urban 
agriculture, city farms, home gardens, residential yard management, urban forests, residential gardens, botanic gardens, parks, allotment gardens, therapeutic gardens, school gardens etc.) combined with an explicit focus on social dimensions, mentioned in the abstract. Social dimensions in this initial phase of the exclusion/inclusion process, were broadly defined, including for example studies with focus on sustainability (which broadly interpreted include social dimensions [53]), and health (which according to the original WHO definition, as well as more recent conceptions, includes a social dimension as well [54]). This entails excluding studies that not specifically used the term 'community gardens', and excluding studies that explicitly in the abstracts solely focus on physical dimensions of health, such as fruit and vegetable consumption and physical activity, as well as food security, water resources, soil health, biological and agrological diversity etc. Additionally, only studies in English and from USA, Canada, Australia, New Zealand, or Europe were included, just as studies representing peer reviewed articles (excluding dissertations, doctoral theses, conference abstracts etc.) and original research based on primary data (excluding reviews, meta-analyses, studies solely based on theoretical analysis of secondary data, commentaries etc.) were included.

From the 68 articles, further 33 were excluded based on whether the studied urban community gardens studied social dimensions resembling the overall working definition of social capital as social networks and the norms and sanctions that govern their character (without necessarily explicitly focusing on or mentioning social capital), and more specifically bonding, bridging and/or linking social capital, as defined above.

Table 2. Overview of studies included.

\begin{tabular}{|c|c|c|c|c|c|}
\hline Studies & Objective & Study design & Location & $\begin{array}{l}\text { Community gardens } \\
\text { (and/or related } \\
\text { studied phenomena) }\end{array}$ & $\begin{array}{l}\text { Social Capital (or } \\
\text { related) study } \\
\text { parameter/pheno } \\
\text { mena }\end{array}$ \\
\hline $\begin{array}{l}\text { Agustina, I., and } \\
\text { Beilin, R. (2012) }\end{array}$ & $\begin{array}{l}\text { Investigate the adaptation of } \\
\text { migrants in community } \\
\text { gardens, by considering the } \\
\text { extent to which cultural } \\
\text { practices in gardening affect } \\
\text { ability to adapt to the host } \\
\text { country. }\end{array}$ & $\begin{array}{l}\text { Qualitative. } \\
\text { Interviews. }\end{array}$ & $\begin{array}{c}\text { Melbourne, } \\
\text { Australia }\end{array}$ & Community gardens & $\begin{array}{c}\text { Social } \\
\text { connections and } \\
\text { adaption. }\end{array}$ \\
\hline $\begin{array}{l}\text { Alaimo, K., T. M. } \\
\text { Reischl, and J. O. } \\
\text { Allen (2010) }\end{array}$ & $\begin{array}{c}\text { Examines associations } \\
\text { between participation in } \\
\text { community } \\
\text { gardens/beautification projects } \\
\text { and neighborhood meetings } \\
\text { with perceptions of social } \\
\text { capital }\end{array}$ & $\begin{array}{l}\text { Quantitative. Data } \\
\text { from a } \\
\text { cross-sectional } \\
\text { stratified random } \\
\text { survey. }\end{array}$ & $\begin{array}{c}\text { Flint, Michigan, } \\
\text { USA }\end{array}$ & $\begin{array}{l}\text { Community gardens, } \\
\text { beautification projects } \\
\text { and neighborhood } \\
\text { meetings. }\end{array}$ & $\begin{array}{l}\text { Perceptions of } \\
\text { communitarian } \\
\text { and social } \\
\text { network } \\
\text { perspectives of } \\
\text { social capital. }\end{array}$ \\
\hline $\begin{array}{l}\text { Armstrong, D. } \\
\quad(2000)\end{array}$ & $\begin{array}{l}\text { Examine characteristics of } \\
\text { twenty community garden } \\
\text { programs in New York to } \\
\text { identity how they facilitate } \\
\text { neighborhood development } \\
\text { and health promotion. }\end{array}$ & $\begin{array}{c}\text { Standardized } \\
\text { structured telephone } \\
\text { interviews }\end{array}$ & New York, USA & Community gardens & $\begin{array}{l}\text { Neighborhood } \\
\text { development }\end{array}$ \\
\hline Baker, L. E. (2004) & $\begin{array}{l}\text { Studies community gardens in } \\
\text { relation to food citizenship, } \\
\text { food security, urban spaces, } \\
\text { the network of organizations, } \\
\text { and the social and cultural } \\
\text { pluralism. }\end{array}$ & $\begin{array}{l}\text { Participatory } \\
\text { research. Field } \\
\text { work, qualitative } \\
\text { interviews. }\end{array}$ & Toronto, Canada & Community gardens & $\begin{array}{l}\text { The network of } \\
\text { organizations, } \\
\text { social and } \\
\text { cultural } \\
\text { pluralism. }\end{array}$ \\
\hline $\begin{array}{l}\text { Bendt, P., S. } \\
\text { Barthel, and J. } \\
\text { Colding (2013) }\end{array}$ & $\begin{array}{l}\text { Analyze environmental } \\
\text { learning and factors that } \\
\text { influence participation and } \\
\text { boundary interaction in } \\
\text { community gardens }\end{array}$ & $\begin{array}{l}\text { Qualitative. } \\
\text { Interviews } \\
\text { combined with field } \\
\text { observations. }\end{array}$ & Berlin, Germany & $\begin{array}{l}\text { Public-access } \\
\text { community gardens } \\
\text { (abbreviated as } \\
\text { 'PAC-gardens') }\end{array}$ & $\begin{array}{l}\text { Learning } \\
\text { communities and } \\
\text { factors that } \\
\text { influence } \\
\text { participation and } \\
\text { boundary } \\
\text { interaction }\end{array}$ \\
\hline $\begin{array}{c}\text { Borcic, L. S., } \\
\text { Cvitanovic, M., } \\
\text { \&Lukic, A. (2016) }\end{array}$ & $\begin{array}{l}\text { Analyze community gardens } \\
\text { in a (post)socialist setting } \\
\text { during a time } \\
\text { of key changes in their } \\
\text { perception and management. }\end{array}$ & $\begin{array}{l}\text { Qualitative. } \\
\text { semi-structured } \\
\text { interviews, } \\
\text { non-participatory } \\
\text { observation. } \\
\end{array}$ & Zagreb, Croatia & Community gardens & $\begin{array}{l}\text { Social benefits of } \\
\text { gardening. }\end{array}$ \\
\hline
\end{tabular}




\begin{tabular}{|c|c|c|c|c|c|}
\hline $\begin{array}{l}\text { Chan, J., DuBois, } \\
\text { B., \& Tidball, K. G. } \\
\text { (2015) }\end{array}$ & $\begin{array}{l}\text { Analyze the meaning and } \\
\text { relevance of community } \\
\text { gardens in the resilience and } \\
\text { recovery of local residents } \\
\text { and community garden } \\
\text { members after hurricane. }\end{array}$ & $\begin{array}{l}\text { Qualitative. Participant } \\
\text { observation, } \\
\text { qualitative interviews, } \\
\text { and archival research. }\end{array}$ & $\begin{array}{l}\text { New York, } \\
\text { USA }\end{array}$ & Community gardens & $\begin{array}{c}\text { Resilience, } \\
\text { supportive } \\
\text { communities and } \\
\text { social networks }\end{array}$ \\
\hline $\begin{array}{l}\text { Drake, L., \& } \\
\text { Lawson, L. J. } \\
\quad(2015)\end{array}$ & $\begin{array}{l}\text { Analyze community garden } \\
\text { management's shared } \\
\text { experiences across different } \\
\text { contexts. }\end{array}$ & $\begin{array}{l}\text { Mainly quantitative. } \\
\text { Questionnaire (with } \\
\text { some qualitative } \\
\text { elements). }\end{array}$ & $\begin{array}{l}\text { USA \& } \\
\text { Canada }\end{array}$ & Community gardens & Networks \\
\hline $\begin{array}{l}\text { Firth, C, Damian } \\
\text { M., and D. Pearson } \\
\quad(2011)\end{array}$ & $\begin{array}{l}\text { Examines the construction of } \\
\text { "community" in community } \\
\text { gardens, and how they benefit } \\
\text { local communities. }\end{array}$ & $\begin{array}{l}\text { Qualitative. Interviews } \\
\text { and ethnographic } \\
\text { techniques. }\end{array}$ & $\begin{array}{l}\text { Nottingham, } \\
\text { UK }\end{array}$ & Community gardens & Social capital \\
\hline Flachs, A. (2010) & $\begin{array}{l}\text { Explores social and cultural } \\
\text { effects of urban community } \\
\text { gardening. }\end{array}$ & $\begin{array}{l}\text { Qualitative. } \\
\text { Fieldwork. }\end{array}$ & $\begin{array}{l}\text { Greater } \\
\text { Cleveland } \\
\text { Area }\end{array}$ & Community gardens & $\begin{array}{c}\text { The use of } \\
\text { gardens as social } \\
\text { spaces }\end{array}$ \\
\hline $\begin{array}{l}\text { Foo, K., Martin, D., } \\
\text { Wool, C., \& Polsky, } \\
\text { C. }(2013)\end{array}$ & $\begin{array}{l}\text { Analyzing access to and } \\
\text { potential ownership of vacant } \\
\text { parcels, in addition to the } \\
\text { political economic forces } \\
\text { driving land-use change. }\end{array}$ & $\begin{array}{l}\text { Qualitative. Focus } \\
\text { groups and } \\
\text { participatory } \\
\text { sketch-mapping. }\end{array}$ & Boston, USA & $\begin{array}{l}\text { Vacant land in urban } \\
\text { areas (including } \\
\text { community gardens) }\end{array}$ & $\begin{array}{l}\text { Perceptions of } \\
\text { urban } \\
\text { neighborhood, } \\
\text { oriented around } \\
\text { well-being and } \\
\text { health. } \\
\end{array}$ \\
\hline $\begin{array}{l}\text { Ghose, R., \& } \\
\text { Pettygrove, M. } \\
\quad(2014)^{\mathrm{a}} \text {. }\end{array}$ & $\begin{array}{l}\text { Employs social network } \\
\text { theories to examine the } \\
\text { process of urban community } \\
\text { garden development }\end{array}$ & $\begin{array}{l}\text { Qualitative. Case } \\
\text { study. } \\
\text { Semi-structured, } \\
\text { interviews. }\end{array}$ & $\begin{array}{c}\text { City of } \\
\text { Milwaukee, } \\
\text { Wisconsin, } \\
\text { USA }\end{array}$ & Community gardens & $\begin{array}{l}\text { Network } \\
\text { formations }\end{array}$ \\
\hline $\begin{array}{c}\text { Ghose, R., \& } \\
\text { Pettygrove, M. } \\
(2014)^{\mathrm{b}} \text {. }\end{array}$ & $\begin{array}{l}\text { Investigates urban community } \\
\text { gardens as spaces of } \\
\text { citizenship, and the impacts of } \\
\text { community gardens on } \\
\text { citizenship practice and the } \\
\text { effects of volunteerism on the } \\
\text { development of community } \\
\text { gardens. }\end{array}$ & $\begin{array}{l}\text { Qualitative. } \\
\text { Semi-structured } \\
\text { interviews and } \\
\text { participant } \\
\text { observation. }\end{array}$ & $\begin{array}{l}\text { City of } \\
\text { Milwaukee, } \\
\text { Wisconsin, } \\
\text { USA }\end{array}$ & Community gardens & $\begin{array}{l}\text { Citizenship } \\
\text { practice and the } \\
\text { effects of } \\
\text { volunteerism. }\end{array}$ \\
\hline $\begin{array}{l}\text { Glover, T. D. } \\
\text { (2004) }\end{array}$ & $\begin{array}{l}\text { Narrative inquiry exploring a } \\
\text { community garden as a social } \\
\text { context where social capital is } \\
\text { produced, accessed, and used } \\
\text { by community gardeners. }\end{array}$ & $\begin{array}{l}\text { Qualitative. } \\
\text { Face-to-face, narrative } \\
\text { interviews. }\end{array}$ & $\begin{array}{c}\text { A } \\
\text { mid-sized city } \\
\text { located in } \\
\text { Midwestern } \\
\text { USA } \\
\end{array}$ & Community gardens & Social capital \\
\hline $\begin{array}{l}\text { Glover, T. D., } \\
\text { Parry, } \\
\text { D. C., \& Shinew, K. } \\
\text { J. (2005) }\end{array}$ & $\begin{array}{l}\text { Exploring how community } \\
\text { gardeners use their social } \\
\text { capital to access resources to } \\
\text { forward the growth and } \\
\text { development of their } \\
\text { community gardens. }\end{array}$ & $\begin{array}{l}\text { Qualitative. In depth } \\
\text { telephone interviews, } \\
\text { focus group, and field } \\
\text { interviews. }\end{array}$ & St. Louis, USA & Community gardens & Social capital \\
\hline $\begin{array}{l}\text { Hale, J., Knapp, C., } \\
\text { Bardwell, L., } \\
\text { Buchenau, M., } \\
\text { Marshall, J., } \\
\text { Sancar, F., \& Litt, J. } \\
\text { S. (2011) } \\
\end{array}$ & $\begin{array}{l}\text { Explores gardeners' tactile, } \\
\text { emotional, and value-driven } \\
\text { responses to the gardening } \\
\text { experience and how these } \\
\text { responses influence health at } \\
\text { various ecological levels. }\end{array}$ & $\begin{array}{c}\text { Qualitative. } \\
\text { Participatory research } \\
\text { including } \\
\text { key-informant } \\
\text { interviews. }\end{array}$ & Denver, USA & Community gardens & $\begin{array}{l}\text { Social aspects of } \\
\text { community } \\
\text { gardening }\end{array}$ \\
\hline $\begin{array}{l}\text { Hanna, A. K., \& } \\
\text { Oh, P. (2000) }\end{array}$ & $\begin{array}{l}\text { Analyze potentials of urban } \\
\text { community gardens, } \\
\text { exploring a poor } \\
\text { neighborhood through } \\
\text { noneconomic logic. }\end{array}$ & $\begin{array}{l}\text { Mixed methods. Field } \\
\text { work. Qualitative } \\
\text { interviews and survey. }\end{array}$ & $\begin{array}{l}\text { West } \\
\text { Philadelphia, } \\
\text { USA. }\end{array}$ & Community gardens & $\begin{array}{l}\text { Neighborhood } \\
\text { improvement and } \\
\text { developing a } \\
\text { sense of } \\
\text { community } \\
\end{array}$ \\
\hline $\begin{array}{l}\text { Harris, N., Minniss, } \\
\text { F. R., \& Somerset, } \\
\text { S. (2014) }\end{array}$ & $\begin{array}{l}\text { Explores refugees connecting } \\
\text { with a new country through } \\
\text { community food gardening. }\end{array}$ & $\begin{array}{c}\text { Qualitative. Case } \\
\text { study, semi-structured } \\
\text { interviews. }\end{array}$ & $\begin{array}{l}\text { City of Logan, } \\
\text { Australia. }\end{array}$ & $\begin{array}{l}\text { Community food } \\
\text { gardens }\end{array}$ & $\begin{array}{l}\text { Humanitarian } \\
\text { migrant's } \\
\text { connectedness } \\
\text { with their new } \\
\text { country. } \\
\end{array}$ \\
\hline $\begin{array}{l}\text { Hartwig, K. A., \& } \\
\text { Mason, M. (2016) }\end{array}$ & $\begin{array}{l}\text { Examine community gardens } \\
\text { as health promotion } \\
\text { intervention for refugees and } \\
\text { immigrants. }\end{array}$ & $\begin{array}{c}\text { Mixed method } \\
\text { evaluation. } \\
\text { Quantitative data from } \\
\text { surveys and focus } \\
\text { group interviews. }\end{array}$ & $\begin{array}{l}\text { Minnesota, } \\
\text { USA }\end{array}$ & Community gardens & Social support \\
\hline
\end{tabular}




\begin{tabular}{|c|c|c|c|c|c|}
\hline Holland, D. (2004) & $\begin{array}{l}\text { Analyzes the UK community } \\
\text { garden movement as a model } \\
\text { for the implementation of } \\
\text { social, economic and } \\
\text { environmental policies at the } \\
\text { local level. }\end{array}$ & $\begin{array}{l}\text { Mixed methods. } \\
\text { Questionnaire and } \\
\text { in-depth interviews. }\end{array}$ & UK & $\begin{array}{l}\text { Community gardens } \\
\text { and city farms }\end{array}$ & $\begin{array}{l}\text { Sustainability, } \\
\text { diversity and } \\
\text { connections. }\end{array}$ \\
\hline $\begin{array}{l}\text { Kimberly, J., Troy, } \\
\text { D., Diana, C., } \\
\text { Shinew, K. J., } \\
\text { Glover, T. D., \& } \\
\text { Parry, D. C. (2004) }\end{array}$ & $\begin{array}{c}\text { Examine whether urban } \\
\text { community gardens are } \\
\text { construed as spaces where } \\
\text { people of different races can } \\
\text { successfully interact. }\end{array}$ & $\begin{array}{l}\text { Structured } \\
\text { telephone } \\
\text { interviews. }\end{array}$ & $\begin{array}{l}\text { Greater St. Louis } \\
\text { Region, USA }\end{array}$ & Community gardens & $\begin{array}{l}\text { Interactions of } \\
\text { people of } \\
\text { different races. }\end{array}$ \\
\hline $\begin{array}{l}\text { Kingsley, J., \& } \\
\text { Townsend, M. } \\
\quad(2006)\end{array}$ & $\begin{array}{l}\text { Explores the concept of social } \\
\text { capital within an urban } \\
\text { community garden to } \\
\text { understand the significance of } \\
\text { the social connections made. }\end{array}$ & $\begin{array}{l}\text { Qualitative. } \\
\text { Interviews }\end{array}$ & $\begin{array}{l}\text { Melbourne, } \\
\text { Australia }\end{array}$ & Community gardens & Social capital \\
\hline $\begin{array}{c}\text { Kingsley, J., M. } \\
\text { Townsend, and C. } \\
\text { Henderson-Wilson } \\
\text { (2009) }\end{array}$ & $\begin{array}{l}\text { Investigate the ways in which } \\
\text { a garden community } \\
\text { contributes to the } \\
\text { enhancement of health, } \\
\text { wellbeing and contact with } \\
\text { nature for urban dwellers. }\end{array}$ & $\begin{array}{l}\text { Qualitative. } \\
\text { Interviews. }\end{array}$ & $\begin{array}{l}\text { Melbourne, } \\
\text { Australia }\end{array}$ & Community gardens & $\begin{array}{l}\text { Health, which } \\
\text { includes } \\
\text { "satisfactory } \\
\text { human } \\
\text { relationships". }\end{array}$ \\
\hline $\begin{array}{l}\text { Litt, J., Schmiege, } \\
\text { S., Hale, J., } \\
\text { Buchenau, M., \& } \\
\text { Sancar, F. (2015). }\end{array}$ & $\begin{array}{l}\text { Exploring ecological, } \\
\text { emotional and social levers of } \\
\text { self-rated health for urban } \\
\text { gardeners and non-gardeners. }\end{array}$ & $\begin{array}{l}\text { Mainly quantitative } \\
\text { Survey, Street } \\
\text { environment data, } \\
\text { area-level measures. }\end{array}$ & $\begin{array}{c}\text { Denver, } \\
\text { Colorado, USA }\end{array}$ & $\begin{array}{l}\text { Urban community } \\
\text { gardens }\end{array}$ & $\begin{array}{c}\text { Social } \\
\text { involvement and } \\
\text { collective } \\
\text { efficacy } \\
\end{array}$ \\
\hline Macias, T. (2008) & $\begin{array}{l}\text { Examine the impact of local } \\
\text { agriculture on local } \\
\text { communities with focus on } \\
\text { food equity, social } \\
\text { integration, and natural } \\
\text { human capital }\end{array}$ & $\begin{array}{l}\text { Qualitative. } \\
\text { Semi-structured } \\
\text { interviews }\end{array}$ & $\begin{array}{l}\text { Burlington, } \\
\text { Vermont, USA }\end{array}$ & $\begin{array}{l}\text { Community based } \\
\text { agriculture (including } \\
\text { community gardens) }\end{array}$ & Social integration \\
\hline $\begin{array}{l}\text { Martin, G., Clift, } \\
\text { R., \& Christie, I. } \\
\text { (2016) }\end{array}$ & $\begin{array}{l}\text { Weighs the nutritional, } \\
\text { ecological, and social } \\
\text { sustainability contributions } \\
\text { of urban agriculture by } \\
\text { examining three cases } \\
\text { (including a community } \\
\text { garden in the core of New } \\
\text { York). }\end{array}$ & $\begin{array}{c}\text { Exploratory } \\
\text { qualitative research. } \\
\text { Field-observations, } \\
\text { verbal information } \\
\text { provided by } \\
\text { informants, archival } \\
\text { data, online } \\
\text { research. } \\
\end{array}$ & New York, USA & $\begin{array}{l}\text { Urban cultivation } \\
\text { (including a } \\
\text { community garden } \\
\text { case). }\end{array}$ & $\begin{array}{c}\text { Social } \\
\text { Sustainability }\end{array}$ \\
\hline $\begin{array}{l}\text { McMillen, H., } \\
\text { Campbell, L. K., } \\
\text { Svendsen, E. S., \& } \\
\text { Reynolds, R. } \\
\text { (2016). }\end{array}$ & $\begin{array}{l}\text { Examine, identify and } \\
\text { characterize the type of } \\
\text { grounded, empirically } \\
\text { observable stewardship } \\
\text { practices that demonstrate a } \\
\text { range of indicators of social } \\
\text { resilience at the community } \\
\text { level: place attachment, social } \\
\text { cohesion, social networks, } \\
\text { and knowledge exchange and } \\
\text { diversification. }\end{array}$ & $\begin{array}{l}\text { Qualitative. Case } \\
\text { studies. Participant } \\
\text { observation, } \\
\text { unstructured \& } \\
\text { semi-structured } \\
\text { interviews. } \\
\text { Workshops with } \\
\text { local residents. }\end{array}$ & New York, USA & Community garden & $\begin{array}{l}\text { Social resilience, } \\
\text { including social } \\
\text { cohesion and } \\
\text { social networks } \\
\text { as stewardship } \\
\text { practices. }\end{array}$ \\
\hline $\begin{array}{l}\text { Ober, J., Mph, A., } \\
\text { Alaimo, K., Elam, } \\
\text { D. Perry, E., Ober, } \\
\text { J. } \\
\text { Elam, D. (2009) }\end{array}$ & $\begin{array}{l}\text { Examines whether engaging a } \\
\text { diverse group of partners with } \\
\text { a combination of research } \\
\text { training and local knowledge } \\
\text { and expertise, reciprocal } \\
\text { transfers of knowledge would } \\
\text { occur in community gardens. }\end{array}$ & $\begin{array}{l}\text { Qualitative. } \\
\text { Participant } \\
\text { observation and } \\
\text { interviews }\end{array}$ & $\begin{array}{l}\text { Flint, Michigan, } \\
\text { USA }\end{array}$ & Community gardens & $\begin{array}{l}\text { Relationships and } \\
\text { interpersonal } \\
\text { skills. }\end{array}$ \\
\hline
\end{tabular}




\begin{tabular}{|c|c|c|c|c|c|}
\hline $\begin{array}{l}\text { Ohmer, M L., P. } \\
\text { Meadowcraft, K. } \\
\text { Freed, and E. Lewis } \\
\text { (2009) }\end{array}$ & $\begin{array}{l}\text { Examines a community } \\
\text { conservation program, aiming } \\
\text { at revitalization through } \\
\text { community gardens, and } \\
\text { gateway green spaces, } \\
\text { primarily in distressed urban } \\
\text { areas. Analyzes the } \\
\text { individual, social, and } \\
\text { community benefits of the } \\
\text { program for garden volunteers } \\
\text { and participating } \\
\text { communities. }\end{array}$ & $\begin{array}{l}\text { Mixed methods. } \\
\text { Interviews and } \\
\text { surveys. }\end{array}$ & $\begin{array}{c}\text { Western } \\
\text { Pennsylvania, } \\
\text { USA }\end{array}$ & $\begin{array}{c}\text { Community } \\
\text { agriculture and } \\
\text { conservation } \\
\text { initiatives (including } \\
\text { community gardens) }\end{array}$ & $\begin{array}{l}\text { Revitalizing } \\
\text { neighborhoods, } \\
\text { beliefs and } \\
\text { behavior } \\
\text { regarding } \\
\text { conservation } \\
\text { issues, sense of } \\
\text { community, and } \\
\text { volunteerism. }\end{array}$ \\
\hline $\begin{array}{l}\text { Pearson, D. H., \& } \\
\text { Firth, C. (2012) }\end{array}$ & $\begin{array}{l}\text { Investigate differences in } \\
\text { community gardens in regard } \\
\text { to management, funding, size, } \\
\text { participants, and motivations. }\end{array}$ & $\begin{array}{l}\text { Mixed methods } \\
\text { exploratory } \\
\text { methodology. } \\
\text { Questionnaire and } \\
\text { interviews. } \\
\end{array}$ & $\begin{array}{l}\text { East Midlands } \\
\text { Region, UK }\end{array}$ & Community gardens & $\begin{array}{l}\text { Participants in } \\
\text { community } \\
\text { gardens }\end{array}$ \\
\hline Rosol, M. (2010) & $\begin{array}{c}\text { Examines citizen participation } \\
\text { in the governance of urban } \\
\text { green space. }\end{array}$ & $\begin{array}{l}\text { Qualitative. } \\
\text { Semi-structured } \\
\text { interviews and } \\
\text { group interviews. }\end{array}$ & Berlin, Germany & $\begin{array}{c}\text { Urban green space } \\
\text { (including community } \\
\text { gardens) }\end{array}$ & $\begin{array}{c}\text { Citizen } \\
\text { participation }\end{array}$ \\
\hline $\begin{array}{l}\text { Saldivar-Tanaka, } \\
\text { L., \& Krasny, M. E. } \\
\text { (2004) }\end{array}$ & $\begin{array}{l}\text { The role Latino community } \\
\text { gardens play in community } \\
\text { development, open space, and } \\
\text { civic agriculture. }\end{array}$ & $\begin{array}{l}\text { Qualitative. } \\
\text { Interviews and field } \\
\text { observations. }\end{array}$ & New York, USA & $\begin{array}{l}\text { Latino community } \\
\text { gardens }\end{array}$ & $\begin{array}{l}\text { Community } \\
\text { development }\end{array}$ \\
\hline $\begin{array}{l}\text { Shan, H., \& Walter, } \\
\text { P. (2015) }\end{array}$ & $\begin{array}{l}\text { Examine practice-based } \\
\text { learning with focus on } \\
\text { knowing, connecting, and } \\
\text { hybrid knowledge production } \\
\text { across cultures, emerging } \\
\text { through experiences of } \\
\text { Chinese immigrants in } \\
\text { community gardens on a } \\
\text { university campus. }\end{array}$ & $\begin{array}{l}\text { Qualitative. Face to } \\
\text { face Interviews. }\end{array}$ & $\begin{array}{l}\text { Vancouver, } \\
\text { British Columbia, } \\
\text { Canada. }\end{array}$ & Community gardens & $\begin{array}{l}\text { Ways of learning } \\
\text { that foster } \\
\text { knowing, } \\
\text { connecting, and } \\
\text { hybrid knowledge } \\
\text { production across } \\
\text { cultures. }\end{array}$ \\
\hline $\begin{array}{c}\text { Shinew, K. J., } \\
\text { Glover, T. D., \& } \\
\text { Parry, D. C. (2004) }\end{array}$ & $\begin{array}{l}\text { Examine whether urban } \\
\text { community gardens are } \\
\text { construed as spaces where } \\
\text { people of different races can } \\
\text { successfully interact. }\end{array}$ & $\begin{array}{l}\text { Structured } \\
\text { telephone } \\
\text { interviews with a } \\
\text { stratified sample. }\end{array}$ & $\begin{array}{l}\text { Greater St. Louis } \\
\text { Region, USA }\end{array}$ & Community gardens & $\begin{array}{l}\text { Successful } \\
\text { interracial } \\
\text { interaction and } \\
\text { relations and } \\
\text { social capital. }\end{array}$ \\
\hline $\begin{array}{l}\text { Teig, E., Amulya, } \\
\text { J., Bardwell, L., } \\
\text { Buchenau, M., } \\
\text { Marshall, J. A., \& } \\
\text { Litt, J. S. (2009) }\end{array}$ & $\begin{array}{l}\text { Examine the social processes } \\
\text { and the connection between } \\
\text { gardens, garden participation } \\
\text { and health. }\end{array}$ & $\begin{array}{l}\text { Qualitative. } \\
\text { Interviews. }\end{array}$ & $\begin{array}{c}\text { Denver, } \\
\text { Colorado, USA }\end{array}$ & Community gardens & $\begin{array}{l}\text { Collective } \\
\text { efficacy }\end{array}$ \\
\hline $\begin{array}{l}\text { Veen, E. J., Bock, } \\
\text { B. B., den Berg, } \\
\text { W., Visser, A. J., \& } \\
\text { Wiskerke, J. S. C. } \\
\text { (2016) }\end{array}$ & $\begin{array}{l}\text { Investigate how the } \\
\text { community gardens' } \\
\text { organizational designs and } \\
\text { objectives influence social } \\
\text { cohesion. }\end{array}$ & $\begin{array}{l}\text { Mixed methods } \\
\text { case study. } \\
\text { Semi-structured } \\
\text { interviews and } \\
\text { questionnaires. } \\
\end{array}$ & The Netherlands & Community gardens & Social cohesion \\
\hline $\begin{array}{c}\text { Wakefield, S., } \\
\text { Yeudall, F., Taron, } \\
\text { C., Reynolds, J., \& } \\
\text { Skinner, A. (2007) }\end{array}$ & $\begin{array}{l}\text { Health impacts of community } \\
\text { gardens. }\end{array}$ & $\begin{array}{c}\text { Qualitative. } \\
\text { Community based } \\
\text { research. } \\
\text { Participant } \\
\text { observation, focus } \\
\text { groups and in-depth } \\
\text { interviews. }\end{array}$ & Toronto, Canada & Community gardens & $\begin{array}{l}\text { Social health and } \\
\text { community } \\
\text { cohesion. }\end{array}$ \\
\hline
\end{tabular}

As table 2 reveals, six of the studies explicitly examine social capital [1-4], [18], [55], while others focus on closely related concepts or phenomena, such as networks [56-59], integration or adaption of migrants or other marginalized groups [10], [60], [61], social dimensions of sustainability [12], [62], neighborhood development [7], [8], [63], [64], and social aspects of health [65-67] and resilience [59], [68].

A totality of nineteen studies involve research from the US [2], [3], [7], [8], [55], [57-59], [61-64], [66], [68-74], six studies from Europe (three from the UK [1], [12], [75], two from Germany (Berlin) [5], [76] and one from Croatia 
[77]), four from Canada [56], [57], [65], [78], and four from Australia [4], [10], [67], [79]. This confirms a general tendency of a disproportionate mass of research from the US on urban community gardening, compared to Europe and elsewhere. Furthermore, 27 studies are qualitative studies [1-5], [7], [10], [18], [56], [58], [59], [61], [62], [65-71], [73], [76]-[79], five studies are mixed-methods research [12], [63], [64], [72], [75], while only three articles comprises of mainly or entirely quantitative data [8], [55], [57].

\section{Findings and Analysis}

The following section analyzes urban community gardening through the concept of social capital, and examines (1) whether and how it is supported that urban community gardening creates or facilitates bonding, bridging and/or linking social capital, and (2) what we can learn from the included studies in terms of urban community gardens fostering social capital. The analytical technique employed is examining whether and how included articles demonstrate that the studied urban community gardens create bonding, bridging, and/or linking social capital. As the meta-analysis includes 35 articles, it is not possible to unfold a detailed analysis of each study. Consequently, table 3 below presents an overview of the studies included, including whether the studies demonstrate that urban community gardening fosters social capital; bonding, bridging, and/or linking, and elements identified in each study as important in creating social capital in urban community gardens. The criterion for whether studies are identified as demonstrating they create social capital is that they substantiate and/or exemplify (via quotes from interviews or quantitative data) that the studied community garden(s) create social capital. Additionally, some studies demonstrate indications of creating social capital, while other studies, in turn, claim urban community gardens foster social capital, without supporting this with data, while some studies illustrate how social capital can have adverse consequences in the studied community garden(s). The section divides the findings into these three categories, acknowledging that the split is an analytical one, and that it is not always entirely clear whether the type of social capital discussed unequivocally falls into one category, as will be evident below. This is in line with Putnam's point that the different dimensions and categories of social capital by no means necessarily are "either-or' categories into which social networks can be neatly divided..." [36, p. 23].

Table 3. Studies included and social capital.

\begin{tabular}{|c|c|c|c|c|}
\hline $\begin{array}{l}\text { Studies in chronological } \\
\text { order by first author }\end{array}$ & Bonding & Bridging & Linking & $\begin{array}{l}\text { Elements identified as important in creating social capital } \\
\text { in urban community gardens }\end{array}$ \\
\hline Agustina, I., and Beilin, R. (2012) & - & $(\mathrm{X})$ & - & $\begin{array}{l}\text { To establish social connections (and accordingly social } \\
\text { capital) it is important to resolve language barriers } \\
\text { experienced by migrant gardeners. }\end{array}$ \\
\hline $\begin{array}{l}\text { Alaimo, K., Thomas M. Reischl, and J. O. } \\
\text { Allen (2010) }\end{array}$ & - & - & $(\mathrm{X})$ & $\begin{array}{l}\text { Neighborhood meetings can enhance community gardens' } \\
\text { impact on neighborhood residents' perception of social } \\
\text { capital. }\end{array}$ \\
\hline Armstrong, D. (2000) & - & - & - & $\begin{array}{l}\text { Cultivation of gardens communally, rather than only } \\
\text { individual plots, reflects cultural variations of community and } \\
\text { individualism, which supports the importance of cultural } \\
\text { considerations in promoting community organizing through } \\
\text { community gardens. }\end{array}$ \\
\hline Baker, L. E. (2004) & $X(-X)$ & $\mathrm{X}$ & - & $\begin{array}{l}\text { Conflicts between residents and between residents and } \\
\text { management, illustrate the challenges of cross-cultural } \\
\text { organizing. Besides language, cultural, racial, and gendered } \\
\text { conceptions of community participation are also barriers to } \\
\text { overcome. }\end{array}$ \\
\hline $\begin{array}{l}\text { Bendt, } P ., \text { S. Barthel, and } J . \\
\text { Colding (2013) }\end{array}$ & - & $(\mathrm{X})$ & - & $\begin{array}{c}\text { Particularly 'boundary activity' in the gardens is important to } \\
\text { create bridging social capital. }\end{array}$ \\
\hline $\begin{array}{l}\text { Borcic, L. S., Cvitanovic, M., \& Lukic, A. } \\
\text { (2016) }\end{array}$ & $\mathrm{X}$ & - & - & $\begin{array}{l}\text { For the city to continue to benefit from the gardens' multiple, } \\
\text { advantages, it is important that the concept of community } \\
\text { gardens and its positioning as a permanent category is } \\
\text { included in spatial planning documentation. }\end{array}$ \\
\hline $\begin{array}{l}\text { Chan, J., DuBois, B., \& Tidball, K. G. } \\
\text { (2015) }\end{array}$ & $\mathrm{X}$ & - & - & $\begin{array}{l}\text { By serving as safe open spaces, community gardens can } \\
\text { bolster resilience in disaster zones by aiding processes of } \\
\text { recovery and regrowth at multiple levels (both at the } \\
\text { individual and community level). }\end{array}$ \\
\hline Drake, L., \& Lawson, L. J. (2015) & - & - & $((\mathrm{X}))$ & $\begin{array}{c}\text { External partners play a large role in securing resources, so to } \\
\text { establish linking (and potentially bonding and bridging) social } \\
\text { capital it is important to address issues of external } \\
\text { partnerships. }\end{array}$ \\
\hline Firth, C, Damian M., and D. Pearson (2011) & $(\mathrm{X})$ & $\mathrm{X}$ & $((\mathrm{X}))$ & $\begin{array}{l}\text { To promote community development, it is essential that the } \\
\text { garden is initiated and managed by individuals from within } \\
\text { the local community. Examples of bridging social capital are } \\
\text { tied to the food-related activities. }\end{array}$ \\
\hline
\end{tabular}




\begin{tabular}{|c|c|c|c|c|}
\hline Flachs, A. (2010) & - & $(\mathrm{X})$ & - & $\begin{array}{l}\text { By linking organizers with socially conscious people, garden } \\
\text { initiatives provide a social space that fosters networking and } \\
\text { activism. }\end{array}$ \\
\hline $\begin{array}{c}\text { Foo, K., Martin, D., Wool, C., \& Polsky, C. } \\
\text { (2013) }\end{array}$ & - & $((\mathrm{X}))$ & - & $\begin{array}{l}\text { Public-civic partnerships that prioritize use values rather than } \\
\text { solely exchange value through economic growth comprise } \\
\text { one promising way to effectively govern abandoned land (and } \\
\text { thus community gardens) in weak market areas, which in turn } \\
\text { is important to benefit from community garden's social } \\
\text { advantages. }\end{array}$ \\
\hline Ghose, R., \& Pettygrove, M. (2014) ${ }^{a}$ & - & - & $((\mathrm{X}))$ & $\begin{array}{l}\text { It is important to utilize network relationships strategically to } \\
\text { create spaces of engagement to leverage power in order to } \\
\text { develop community gardens on vacant lots, and engage } \\
\text { proactively in networks in order to overcome numerous, } \\
\text { including material resource scarcity and complicated land use } \\
\text { permitting procedures. }\end{array}$ \\
\hline Ghose, R., \& Pettygrove, M. (2014) ${ }^{b}$ & - & $\mathrm{X}$ & - & $\begin{array}{l}\text { It is important to address barriers to participation in } \\
\text { community gardens, specifically residents who lack financial } \\
\text { resources and social connections, so they can directly enjoy } \\
\text { the benefits of community gardens. Examples of bridging } \\
\text { social capital is related to a specific "Kids Working to } \\
\text { Succeed" (KWTS) youth job training program and } \\
\text { food-related activities. }\end{array}$ \\
\hline Glover, T. D. (2004) & $X(-X)$ & $\mathrm{X}$ & - & $\begin{array}{l}\text { It is important to focus on differential access to social capital to } \\
\text { address exclusion mechanisms for people in more } \\
\text { disadvantaged structural positions, in facilitating primarily } \\
\text { bridging social capital. }\end{array}$ \\
\hline $\begin{array}{c}\text { Glover, T. D., Parry, D. C., \& Shinew, K. J. } \\
\text { (2005) }\end{array}$ & $\mathrm{X}$ & $\mathrm{X}$ & $((\mathrm{X}))$ & $\begin{array}{c}\text { Particularly ‘leisure episodes' in the gardens are important in } \\
\text { creating social capital. }\end{array}$ \\
\hline $\begin{array}{l}\text { Hale, J., Knapp, C., Bardwell, L., Buchenau, } \\
\text { M., Marshall, J., Sancar, F., \& Litt, J.S. } \\
\text { (2011). }\end{array}$ & - & $\mathrm{X}$ & - & $\begin{array}{l}\text { It is important that organizations facilitating the development of } \\
\text { community gardens that balance physical interventions with } \\
\text { strategies that empower and engage residents which requires } \\
\text { collaboration in an effort to design places in ways that ensure } \\
\text { the long-term sustainability and community ownership of the } \\
\text { strategy. }\end{array}$ \\
\hline Hanna, A. K., \& Oh, P. (2000). & - & $((\mathrm{X}))$ & - & Not stated \\
\hline $\begin{array}{l}\text { Harris, N., Minniss, F. R., \& Somerset, S. } \\
\text { (2014). }\end{array}$ & - & $((\mathrm{X}))$ & - & $\begin{array}{l}\text { By supporting a reconnection with the familiar activity of } \\
\text { growing food crops, and through enhanced access to culturally } \\
\text { appropriate foods in an environment that values and builds } \\
\text { upon immigrant's social and cultural assets, community garden } \\
\text { participation generates connectedness with their new country } \\
\text { through the allocation of tenure of physical space. }\end{array}$ \\
\hline Hartwig, K. A., \& Mason, M. (2016). & - & $\mathrm{X}$ & - & $\begin{array}{l}\text { The creation of community gardens in collaboration with local } \\
\text { churches that specifically target refugees and immigrants are } \\
\text { especially promising for the gardens to facilitate individual, } \\
\text { family and community benefits. }\end{array}$ \\
\hline Holland, D. (2004) & - & $(\mathrm{X})$ & - & $\begin{array}{l}\text { It is important to have to have an understanding of cultural and } \\
\text { societal features to encourage participation in community } \\
\text { gardens. }\end{array}$ \\
\hline $\begin{array}{l}\text { Kimberly, J., Troy, D., Diana, C., Shinew, K. } \\
\text { J., Glover, T. D., \& Parry, D. C. (2004) }\end{array}$ & - & $\mathrm{X}$ & - & $\begin{array}{l}\text { To create bridging social capital it is important community } \\
\text { gardens establish conditions for working together to achieve } \\
\text { collective aims. }\end{array}$ \\
\hline $\begin{array}{l}\text { Kingsley, J., \& Townsend, } M . \\
\text { (2006) }\end{array}$ & $\mathrm{X}(-\mathrm{X})$ & $\mathrm{X}$ & - & $\begin{array}{l}\text { The design of the garden facilitated the development of social } \\
\text { interaction. Specifically its location in the open parkland, as } \\
\text { this facilitated communication, and made the gardeners feel } \\
\text { secure. }\end{array}$ \\
\hline $\begin{array}{l}\text { Kingsley, J., M. Townsend, and C. } \\
\text { Henderson-Wilson (2009) }\end{array}$ & - & $(\mathrm{X})$ & - & $\begin{array}{l}\text { Highlights the gardens' function as a sanctuary within the } \\
\text { community. Poor infrastructure in the gardens and lack of toilet } \\
\text { facilities can function as exclusionary mechanisms. }\end{array}$ \\
\hline Macias, T. (2008) & - & $((\mathrm{X}))$ & - & $\begin{array}{c}\text { The location of the garden posit a challenge, as lower-income } \\
\text { families may find it particularly inaccessible, which makes it } \\
\text { important to address the location of the garden to create social } \\
\text { inclusion. }\end{array}$ \\
\hline Martin, G., Clift, R., \& Christie, I. (2016) & - & - & - & $\begin{array}{l}\text { Finding volunteer labor is a general problem for community } \\
\text { gardens. The work required is skilled and this limits the } \\
\text { available pool, which mean it is particularly important actively } \\
\text { to address this issue. }\end{array}$ \\
\hline
\end{tabular}




\begin{tabular}{|c|c|c|c|c|}
\hline $\begin{array}{l}\text { McMillen, H., Campbell, L. K., Svendsen, E. } \\
\text { S., \& Reynolds, R. (2016). }\end{array}$ & - & $((\mathrm{X}))$ & - & $\begin{array}{l}\text { Going beyond the specific management of the site, it is seen the } \\
\text { way that interaction and sociability enabled through gardening } \\
\text { can strengthen reciprocity among members. }\end{array}$ \\
\hline $\begin{array}{l}\text { Ober, J., Mph, A., Alaimo, K., } \\
\text { Elam, D., Perry, E., Ober, J. Elam, D. } \\
\text { (2009). }\end{array}$ & $\mathrm{X}$ & $\mathrm{X}$ & - & $\begin{array}{l}\text { Identify time as a key factor influencing both the diversity of } \\
\text { membership (bridging social capital) and the depth of social } \\
\text { capital (bonding social capital). }\end{array}$ \\
\hline $\begin{array}{c}\text { Ohmer, M L., P. Meadowcraft, K. Freed, and } \\
\text { E. Lewis (2009) }\end{array}$ & - & $\mathrm{X}$ & - & $\begin{array}{l}\text { Community gardens have potentials for constructive activity } \\
\text { for youth, which is especially valuable, when youth and } \\
\text { children have a lot of free time and few recreational } \\
\text { opportunities in distressed urban areas }\end{array}$ \\
\hline Pearson, D. H., \& Firth, C. (2012) & - & $(\mathrm{X})$ & - & $\begin{array}{l}\text { To enhance community garden's durability, it seems that they } \\
\text { should create a sense of ownership from within the local } \\
\text { community as well as ensure that they are managed in ways } \\
\text { that are consistent with the tenure of their funding sources and } \\
\text { their volunteers' aspirations }\end{array}$ \\
\hline Rosol, M. (2010) & - & $\mathrm{X}$ & - & $\begin{array}{l}\text { Insofar as a new acceptance of urban community gardens is not } \\
\text { a general appreciation of independently run green spaces and } \\
\text { the support is only for temporary uses of urban brownfield } \\
\text { sites, the tenure of community gardens is fragile. }\end{array}$ \\
\hline $\begin{array}{c}\text { Saldivar-Tanaka, L., \& Krasny, M. E. } \\
\text { (2004) }\end{array}$ & - & $\mathrm{X}$ & $((\mathrm{X}))$ & $\begin{array}{l}\text { Land tenure is a main problem cited by gardeners and garden } \\
\text { managers Gardens lacking strong leadership seem especially } \\
\text { vulnerable to losing their city lease. Lack of resources, such as } \\
\text { water, tools, soil, and plant and building materials, is the } \\
\text { second biggest problem. }\end{array}$ \\
\hline Shan, H., \& Walter, P. (2015). & . & $\mathrm{X}$ & - & $\begin{array}{l}\text { It is important to note that when people learn across difference, } \\
\text { they do not learn to fill empty minds or deficit characters of } \\
\text { one cultural group versus another. Such learning is necessarily } \\
\text { a hybrid process where people invoke and enact their past } \\
\text { knowledge and present sensitivity. }\end{array}$ \\
\hline $\begin{array}{l}\text { Shinew, K. J., Glover, T. D., \& Parry, D. C. } \\
\text { (2004) }\end{array}$ & - & $\mathrm{X}$ & - & $\begin{array}{l}\text { Community gardens offer a particular promising arena to } \\
\text { encourage and facilitate positive interracial interactions, as a } \\
\text { leisure setting that offer opportunities for equal-status and } \\
\text { cooperative interracial relationships. }\end{array}$ \\
\hline $\begin{array}{l}\text { Teig, E., Amulya, J., Bardwell, L., Buchenau, } \\
\text { M., Marshall, J. A., \& Litt, J. S. (2009) }\end{array}$ & $\mathrm{X}$ & $\mathrm{X}$ & - & $\begin{array}{c}\text { Social connections, reciprocity, mutual trust, civic engagement, } \\
\text { community building, and accordingly social capital, can be } \\
\text { fostered through leadership, neighborhood activities, and } \\
\text { recruitment }\end{array}$ \\
\hline $\begin{array}{l}\text { Veen, E. J., Bock, B. B., den Berg, W., } \\
\text { Visser, A. J., \& Wiskerke, J. S. C. (2016) }\end{array}$ & - & $\mathrm{X}$ & - & $\begin{array}{l}\text { Certain designs attract participants with certain motivations: } \\
\text { neighbourhood-bound gardens and gardens with communal } \\
\text { plots attract gardeners interested in social aspects of gardening; } \\
\text { non-neighbourhood-bound gardens and gardens with } \\
\text { individual plots attract gardeners interested in harvest. }\end{array}$ \\
\hline $\begin{array}{l}\text { Wakefield, S., Yeudall, F., Taron, C., } \\
\text { Reynolds, J., \& Skinner, A. (2007) }\end{array}$ & $((\mathrm{X}))$ & $\mathrm{X}$ & - & $\begin{array}{l}\text { Particular challenges to community gardens and their social } \\
\text { advantages include insecure land tenure and access, } \\
\text { bureaucratic resistance, concerns about soil contamination and } \\
\text { a lack of awareness and understanding by community } \\
\text { members and decision- makers. Therefor ongoing resources to } \\
\text { support gardens in these many roles are important. }\end{array}$ \\
\hline
\end{tabular}

$\mathrm{X}$ It is substantiated and/or exemplified (via quotes from interviews or quantitative data) that the studied community garden(s) create social capital.

$((\mathrm{X}))$ It is substantiated and/or exemplified (via quotes from interviews or quantitative data) that the studied community garden(s) exhibit indications of creating social capital.

(X) It is claimed (but not exemplified or substantiated via quotes from interviews or other data) that the studied community garden(s) create social capital. (X-) It is demonstrated how social capital can have adverse consequences in the studied community garden(s).

\subsection{Bonding Social Capital}

An often cited study, done by Christ Firth, Damian Maye, and David Pearson [1] set out to examine the nature and construction of "community" in community gardens and how they potentially benefit local communities from a case study exploration of two community gardens in Nottingham, UK. The study uses an interpretative methodology, primarily involving qualitative interviews with four key stakeholders who had a role in developing the community gardens, and participant observation. Firth and colleagues claim that "Bonding social capital was generated in each of the case studies ... it was clear from the interviews and supporting observational work that the community garden has ... enhanced levels of bonding social capital [1, p. 561]. The study remarks that one of the community gardens "...offers many opportunities for local people to participate in community activities" and that conversations "...with participants at the time suggested these activities were useful ways to meet other people from the local area" [1, p. 562]. 
Furthermore, as evidence of bonding social capital, community gardening is claimed to provide “...opportunities to volunteer, which ranged from managing the garden to helping out and/or attending events ...The high number of volunteers (58) that the garden can call on, with a group membership system which ... totaled 131, further strengthen local community commitment" [1, p. 562]. Acknowledging the researcher's conversations with participants at the time suggested community garden activities were useful ways to meet other people, it is however not entirely clear how this necessarily creates bonding social capital. That urban community gardening offer opportunities for community activities is hardly a surprise, as this is one of the definitional characteristics of community gardening, and that participants suggest that common garden activities is a useful way to meet other people, is scarcely evidence that people do in fact meet, creating social capital in general and bonding social capital in particular. It is, moreover not entirely clear how the fact that the garden can call on a high number of volunteers and people involved in a group membership necessarily fosters bonding social capital, as the study claims.

However, there are a number of strong examples of studies demonstrating that urban community gardens create bonding social capital [2], [4], [18], [19], [59], [73], [77], as well as studies emphasizing how the bonding social capital created can have adverse effects [2], [4], [56] which will be exemplified below.

Another widely cited study done by leisure researcher Troy Glover in collaboration with Kimberly Shinew and Diana Parry, aims to understand how community gardeners employ their social capital to access resources to forward the growth and development of community gardens in low-to-moderate income neighborhoods, St. Louis, USA [3]. The study use a qualitative methodology; focus group, and field interviews with gardeners. According to the study "...Most of the research participants talked about friendship as a welcome by-product of participation and how it benefited them outside of the community garden" [3, p. 463]. The study thus quotes a gardener who is stating that "I never would have been friends with or even met these people if it hadn't been for the community garden"... and that the community gardening activities are "..a real connecting thing" [3, p. 463-64]. The trust emerging from people helping each other in the gardens, according to the study, "...helped transform formal relationships in the garden context into genuine friendships" which is an indication of bonding social capital created in the gardens, and the "...social capital produced, and thus the relationships built, were clearly essential to the gardens' continued survival" [3, p. 463]. Glover and colleagues are drawing on social capital researcher Lin's distinction between strength-of-strong ties and strength-of-weak-ties and analysis that the stronger the tie, the more likely that the social capital accessed will positively affect the success of expressive action, and the weaker the tie the more likely ego will have access to better social capital for instrumental action. It is thus noted that "...strong ties among the members of the community garden networks gave the networks access to resources that helped maintain and preserve their gardens" which is illustrated by "..members who shared their own equipment (e.g. water, tools, backhoe) or skills (e.g. ideas, labor) to assist with the collective garden effort" [3, p. 466].

In a another qualitative study, Troy Glover used a narrative approach and interviewed 14 community gardeners living in the same neighborhood in a mid-size city of the Midwestern USA [2]. Glover explores a community garden as a social context wherein social capital is generated, accessed, and used by a social network of community gardeners. The study focus on the distribution of social capital among the members of the garden group, that is, the strength of ties among gardeners and its implications for access to the collective resources within the gardening network. Glover analyzes that the community garden project capitalized on, and evidently added to, the accumulation of social capital [2, p. 150] and gives several examples from the interviews of how both participants in the community garden and members of the local community experience the garden as a project and site that foster social capital. For example, Glover quotes a core-member and head community gardener as stating that “...We've got a pretty good network going on here", and a garden-volunteer and non-core member as saying that "Now I know people that I have things in common with", and another core-member of the community garden, commenting on the garden's resulting network; "It feels like a neighborhood" [2, p. 150-51]. According to Glover the garden accordingly "...encouraged people to grow closer by providing a collective initiative, as well as a physical space, in which they could socialize together" capital [2, p. 150], even though it is remarked that the number of African Americans participating the garden remained small, and that many of the participants, according to Glover, was "...perceived by the African Americans residents [in the neighborhood] as "the white folks' project" [2, p. 154]. A decision to lock the garden fence further complicated relations between the core group and other neighborhood residents "....as well as between African Americans and the primarily Caucasian core group that controlled the key" [2, p. 154]. Accordingly, albeit Glover remark that the community garden gave residents in the neighborhood with disadvantaged structural positions (organized by race and socio-economic status) improved access to resources and social capital, these opportunities were challenged by the disadvantaged group's inability to access the key to unlock the garden gate or have a genuine influence over the decisions made in the garden. The community garden, according to Glover, was "...both a consequence and a source of social capital", that is, as a consequence, it was the result of a persistent network of individuals who formed a garden network committed to its development, and as “... a source of social capital, it strengthened social ties and facilitated further social connections among neighbors" $[19$, p. 156]. However, a 
central insight, identified by Glover, is that the social groups in the study, had differential access to social capital because of their more advantaged or disadvantaged structural positions. Particularly the African American residents were constrained by fear of retribution from other African Americans who were involved in criminal activity, the community garden was trying to displace, as well as constrained by the core group in the community garden who had been part of neighborhood efforts for years, and who “...excluded others from genuinely influencing decisions about the garden" [2, p. 156]. Both instances can be interpreted as a negative source of bonding social capital, where norms and sanctions can work as exclusion mechanisms.

Jonathan Kingsley and Mardie Townsend's study on social capital and community gardens as mechanisms for growing urban social connectedness explores the concept of social capital within the context of an urban community garden in order to understand the significance of the social connections made through community gardens [4]. The research is a qualitative case study, involving interviews with ten key informants from 'Dig In' community gardens, in Melbourne Australia. The garden is established with the intent of creating social capital in collaboration between a local health promotion foundation, the local council, and a local organization dedicated to provide social, educational and recreational activities, and local residents. The garden's mission is thus to provide opportunities for social interaction and healthy recreation, through the shared enjoyment of gardening, and the rules intend to encourage principles of co-operative considerate behavior for people and environmental sustainability for the land [4, p. 528]. Albeit the local area has "... a diverse population" it is identified by the authors that "...the gardeners are predominantly Anglo-Saxon middle-class, female and in their 50s" [4, p. 530]. This is backed up by quotes from the interviews, for example describing the group as "...retired", "a lot of people ... living in apartments", "most people are in their 50 s", who "share [the] same green values" and "culturally there are no differences" $[4$, p. 530]. These are plausible examples of bonding social capital, which is further exemplified in the study as "...ties relating to shared enjoyment of gardening ..." [4, p. 528]. It is however also noteworthy that the study identifies negative impacts of social capital, with an interviewee mentioning an occurrence of social discrimination with a girl with mental problems, whom the members discussed whether she should be excluded from the garden, and tension with the neighboring soccer club.

Another example of bonding social capital created in urban community gardens, as well as negative impacts of the created bonds is exhibited in Laureen Bakers' case study of three community gardens in Toronto, Canada [56]. Granting the study primarily concentrates on the complexities of food citizenship and food security, the article attends to the role gardener's play in transforming urban spaces, the complex network of organizations working cooperatively and the way in which social and cultural pluralism through community gardens are shaping the urban landscape. In one of the community gardens, located in a neighborhood that is one of the fastest-growing, most densely populated areas in Toronto, Canada, with the city's highest level of new immigrants, and high unemployment rate. While Baker refers to a story from two gardeners regarding how they used to pass each other "... without so much as a smile. Since the community garden was started..." they "...have shared recipes, gardening tips, and a new friendship." the community garden also, according to Baker, reveals the complexity of social relationships in this diverse community. Baker thus notes “...Sri Lankan gardeners formed the majority of people on the garden committee, creating tension between themselves and non-Tamil residents. ..." [56, p. 320]. Baker elaborates that these conflicts between residents, illustrate the challenges of cross-cultural organizing, and that "...language is not the only hindrance in mediating conflicts; cultural, racial, and gendered conceptions of community participation are also barriers" [56, p. 320], which plausibly could interpreted as negative consequences of bonding social capital.

In another study and context, Joana Chan and colleagues analyze the meaning and relevance of community garden spaces in the resilience and recovery of local residents and community garden members after the hurricane Sandy in New York in 2012 [59]. They use an ethnographic approach, comprising of participant observation, qualitative interviews, and archival research, in five community gardens. The overall findings in the article indicate that community gardens functioned as multi-purpose community refuges that hosted meaningful and restorative greening practices, and developed supportive communities. Specifically, it is elaborated how selected gardens in the study established strong social network that supported the local community, thereby facilitating communication and aid to neighbors and gardeners in need both before and after the storm [59]. Gardeners returned immediately to the garden after the storm, digging out and replanting the garden by hand. They used the garden as a social gathering space and in the two years following the storm as a space to plan activism in an effort to protect the garden. According to the study, the gardeners expressed their love for gardening, identifying it as a practice that brought them great joy, satisfaction and meaning in their lives before and after Sandy. After Sandy, these community relationships and social support networks were mobilized and cited as central to recovery. This was illustrated most vividly in one of the cases, where the trust and camaraderie nurtured from neighbors working together in the community garden was identified as a source of mutual support and safety [56, p. 631]. A gardener is thus quoted saying that “... look at the 50 people eating homemade chili over an open fire two days after one of the most devastating hurricanes in the East Coast. Standing around joking, having hot chocolate . . . when the National Guard can't even get 
through yet. ... That is the best defense we have against fear. The best defense we have against $\ldots$ any $\ldots$ kind of insecurity. . . And that is a direct result of the community garden. You know being a hub for safety, security. A blanket of support between neighbors." [56, p. 631].

This is entirely consistent with findings from Ellen Teig and fellow researchers' analysis of social processes described by community gardeners, and how these are cultivated by, or supportive of, activities in community gardens, based on fifteen qualitative individual and fourteen group interviews involving residents participating in community gardens in Denver Colorado, USA. The study focus on collective efficacy and the concept of collective efficacy is closely related to the concept of social capital, defined as "the link between mutual trust and a shared willingness to intervene for the common good of the neighborhood" $[19$, p. 1120]. Collective efficacy is in the analysis of the interviews broken down to different social processes described by the gardeners, including social connections, reciprocity, mutual trust, social norms, civic engagement, and community building. All these qualities could be relevant dimensions of both bonding (as trusting and co-operative relations), bridging (as ties bringing people together from diverse socio-demographic situations), and linking (as norms of respect and networks of trusting relationships across explicit, formal or institutionalized power) social capital, depending on how they are employed. Teig and colleagues asserts that "Gardeners ... talked extensively about a high level of trust between members of the garden, often on the strength of being fellow gardeners in the same garden", "Strong social ties developed within the garden through face-to-face contact with other gardeners and involvement in the garden related activities", and that the social connections established in the garden "...developed into genuine friendships and that could be relied upon for support beyond the context of the garden" which is supported by quotes from a garden leader and a gardener [19, $\mathrm{p}$. 1117-19]. The bonding character of social interactions generated in the garden activities, is supported in the analysis of how the mutual trust formed in the gardens also facilitated "...not trusting people outside of the garden" and gardeners "...noted that the stealing of produce or tools from the garden and vandalism of the garden property were issues that made some gardeners mistrust non-gardeners" [19, p. 1117].

\subsection{Bridging Social Capital}

Just as a range of studies demonstrate that urban community garden's create bonding social capital, numerous studies exhibit how the gardens foster bridging social capital [1], [2], [18], [19], [56], [64], [65], [70-73], [76], [78], [8184] as will be exemplified below.

The previously discussed study, completed by Chris Firth, Damian Maye, and David Pearson [1] proclaims that "[p]eople visiting the community garden from other parts of the district" is identified as an "...important source of bridging social capital" [1, p. 563]. As one of the examined community garden's staff members commented, "a few years ago there were barriers between the Asian and Black communities, but these have been broken down as people have joined in our food-related activities" [1, p. 563]. This example and quote is clearly a signal of the community garden fostering bridging social capital, connected to the food-related activities established in relation to the garden.

Another study also mentioned in the section above is the done by Troy Glover he attends to how the community garden bridges across diverse social cleavages and challenges related to this effort. As a response to problems experienced in the neighborhood an interviewee, a non-core member of the garden, remarks that the garden "...brings people together in a non-contentious, non-argumentative, social setting" [2, p. 152]. A core-member of the garden presents a picture from the garden to the interviewer, emphasizing the diversity of the group in the picture, and notes that "...On this particular day the mix of the people working in the garden on these pillars included ... a woman who just bought a house right next to the garden, an African American... who's actually a crook, and a substance abuser" [2, p. 152]. Particularly interesting here, is the involvement of African-Americans in the garden, as this, according Glover, was a positive sign that the neighborhood was improving due to the gardens, and a clear example of bridging social capital produced in the garden.

Another study done by Troy Glover, Kimberly Shinew, and Diana Parry uses structured telephone interviews with 195 community gardeners, selected randomly and stratified by zip code to achieve a representative sample, from a database of community gardeners from the Greater St. Louis Region, USA [18]. The purpose of the study was to examine whether urban community gardens are construed as spaces where people of different races can successfully interact $[18$, p. 336]. As previously specified, race can be a dimension of diverse socio-demographic backgrounds, and particular relevant in contexts where for example race relations between black and white Americans are challenged. This is the case in the study's situated context and climate which have augmented a visible chasm between the two groups [18, p. 340]. The interviews were designed to generate data on a variety of topics, including psychological identification with a group and sense of community, motivation for involvement, and socialization (including interracial socialization). Respondents were asked about trust and socializing aspects, more specifically occurring interracial interactions in the garden, inspired by Putnam [36] and the Social capital community benchmark survey [85]. Whereas the results demonstrated no significant difference between the two racial groups, both groups responded favorably to the statement "Community gardening brings together people who belongs to different racial groups" (on a five point scale: $(1=$ "strongly disagree" to 5 "strongly agree"). Black gardeners had a mean score of 4.04, while white gardeners had a score of 3.91. Furthermore, gardeners agreed to a large 
extent to the statement "Community gardens brings together people who wouldn't normally socialize together" (4.04 for black gardeners and 3.91 for white gardeners) [18, p. 348] . This clearly illustrates that the gardeners in this study perceive that their involvement in community gardening activities creates bridging social capital.

There is a range of other examples of bridging social capital created, where the bridging social capital refers to different forms of intercultural dimensions of socio-demographic situations. These include James Hale and colleagues' research on community gardener's tactile, emotional, and value-driven responses to the garden experience in Denver, USA [71], Kari Hartwig and Meghan Mason's study on community gardens for refugee and immigrant communities in Minnesota, USA [72], Marit Rosol's research on community gardens in Berlin, examining citizen participation in the governance of contemporary urban green space [76], Hongxia Shan and Pierre Walter's research on everyday multiculturalism focusing on Chinese immigrant's community garden experiences in Vancouver, Canada [78], and Laura Saldivar-Tanakal and Marianne Krasny's case study of Latino community gardens in New York City [83], as well as Sarah Wakefield and colleagues' exploration of community gardening in Toronto, Canada [65].

Other examples of bridging social capital demonstrate and exemplifies how the gardens create bridges between generations [68], [70], [72], [76], [83]. These includes for example Rina Ghose and Margaret Pettygrove's examination of urban community gardens as spaces of citizenship, as well as Heather McMillen and colleagues' investigation of stewardship practices [68] and Laura Saldivar-Tanaka1 and Marianne Krasny's case study of Latino community gardens, both conducted in New York [83].

Ghose and Pettygrove's qualitative study examines the impacts of community gardens on citizenship practice and the effects of volunteerism in the development of community gardens study on urban community gardens as spaces of citizenship in Milwaukee, USA, employs semi-structured interviews and participant observation [70]. In one of the cases, the Harambee gardens, located in a neighborhood that suffers from the high crime rates, provide safe recreational and educational space for black youth, who is particularly vulnerable to the high crime of the neighborhood [70, p. $1100]$. One of the gardens is "...designed to allow children to play safely while their parents garden in the same space" [70, p. 1101]. The garden's organizers are consequently quoted stating that children "are always around" and according to the study they "... have been eager to be involved..." as there is "so little green space" in the neighborhood [70, p. 1101]. A garden organizer states that "[There are] four kids that come over and they come over pretty regularly and see what we're up to; they've helped with putting soil in the beds, and they want to plant things and are very curious about what we're up to and excited about learning stuff' [70, p. 1101]. Another garden, the All People's Garden, provides a more formalized opportunity for youth via a local church's "Kids Working to Succeed" youth job training program, which are particularly valued as they are "...perceived to counteract the effects of racism, poverty, unemployment and crime." [70, p. 1101]. The youth participants receive an hourly wage maintain the garden together with church staff, including a church pastor (who also functions as a garden coordinator). The pastor comments that "because we have this pool of young folks, we are able to really support and encourage the individual [adult] gardeners. So, if they don't get to the weeding one week, we can help them out, and then encourage them to come back saying "hey, we took care of your weeds"' [70, p. 1102]. Therefore, Ghose and Pettygrove evaluates that the studied "...community gardens are multigenerational spaces in which youth and adults interact in mutually beneficial ways" [70, p. 1102].

Another example of bridging social capital fostered in urban community gardens is found in Esther Veen and colleagues' research from the Netherlands study whether and how the community gardens' organizational designs and objectives influence social cohesion. The study employ a mixed-methods case study design, involving seven cases with different organizational characteristics in urban community gardens in the Netherlands, using semi-structured interviews (63 in all) and questionnaires (237 returned in all, from gardeners from six of the seven cases). Social cohesion is very broadly defined as people's"... feeling and being connected to each other." $[85$, p. 1272-73], which is operationalized as the "... extent to which community garden participants (1) form relations with each other and (2) offer each other mutual help." [85, p. 1273], which close resembles the present working definition of social capital. The quantitative data from the questionnaires shows that $93 \%$ of the respondents indicated that they chat to others when visiting the gardens, most of them during every visit. While this does not necessarily demonstrate that the gardens create social capital, selected quotes from the qualitative part of the study indicate that the gardens have a bridging function. One interviewee thus articulate that the garden is "...a fine social spot. And that is what it's for. It's like where everyone meets. People talk and so on. It's not a park. It's not a garden. It's really like a village square." Other informants are quoted saying that at the garden "...you really see everyone from this street and also from the other side, everyone comes together. And you speak to people that you [normally] just say hi and bye to just a little longer so the next time you chat to them in the street again. That is how the contacts grow." [85, p. 1282] and "Although the contacts are volatile, it does give a good feeling that you have contacts with your fellows, your neighbours." [85, p. 1283]. Although it is not specified further how these examples are characterized by people meeting across diverse socio-demographic situations, the quotes are plausible examples of cognitive bridging social capital generated in the gardens, as it is stated as a place where "everyone meets" and "everyone comes together". 
While these are different and positive examples of bridging social capital created in the studied urban community gardens, some articles included fails to demonstrate that urban community gardens create bridging social capital, only emphasizing the gardens' opportunities or potentials for social interactions, which can foster bridging social capital, without examples substantiating this via quotes from interviews or other data. This is for example the case in Andrew Flachs qualitative case study, based on fieldwork, regarding the social impacts of community gardens in Greater Cleveland [69]. Flachs thus claim that community gardens “...provide an opportunity for different kinds of people to interact by creating a hierarchy stripped of socioeconomic status..." [69, p. 5], but provides no data to underpin this. As previously emphasized, that urban community gardening offer opportunities for interaction is by no means a surprise, as this is one of the definitional characteristics of community gardening.

\subsection{Linking Social Capital}

Although there are several examples of examples of studies demonstrating that urban community gardens foster bonding and bridging social capital, no studies unfold clear examples of linking social capital created in the gardens. However, four studies show indications of linking social capital [1], [57], [81], [86], and one study claims that linking social capital is created, without documenting this in the presented data [55].

Katherine Alaimo, Thomas M. Reischl, and Julie Ober Allen examine the association between participation in community gardening, beautification projects and neighborhood meetings with perceptions of social capital. The quantitative study is based on data analyzed from a cross-sectional stratified random survey conducted in Flint, Michigan, using hierarchical linear and logistic regression analyses. Alaimo and colleagues claims that the "....results of this study confirms the importance of neighborhood activities for the development of different types of social capital", specifically in regard to participation in either community gardening, beautification projects or neighborhood meetings [55, p. 510]. This statement is supported by the results presented in a table, where involvement in either gardening, neighborhood meetings or both are significantly associated with all the listed markers for social capital except for one specific; "Neighborhood people get along". The table also provide the information that five out of fourteen associations show significantly higher coefficients or odds ratios in the combined group of both gardening and neighborhood meetings compared to either one or both individual groups [55. p. 506]. However, in spite of maintaining that the results"... suggest involvement in neighborhood meetings augment the individual and neighborhood-wide perceptions of social capital associated with community gardening and beautification projects" [55. p. 497], the single statistical significant findings in regard to the connection between both individual and neighborhood level participation in community gardening is concerning linking social capital, where there is a $20 \%$ increase in the level of the perception of linking social capital, here understood as " $[p]$ eople in neighborhood have connections to people who can influence what happens in the neighborhood" [55, p. 508]. Furthermore, as noted, this is both regarding community gardens and beautification activities, so there is no evidence of community gardening increasing the level of linking social capital in this study.

An example of indications of linking social capital is unfolded in the previously mentioned study done by Firth and colleagues, where it is asserted that linking social capital “...was evident ..." in the community gardens studied [1, p. 560]. This is exemplified with noting that one of the gardens was successful in obtaining grant funding, a 'strong' relationship with the local council (although not receiving core funding from the council), and that the garden engages in influencing local policy by being part of a consultative group, while another garden's production of linking social capital is illustrated by stating that "...the local health authority valued the community garden as a health promotion resource..." and that these connections have enabled that garden to "...gain access to resources and funding from health and local authorities" [1, p. 564], albeit no data (e.g. quotes or quantitative data) are presented of this. Thus, while these links indeed are indications of linking social capital, it is not entirely clear how and why exactly these connections are characterized by norms of respect and networks of trusting relationships, which is a prerequisite for linking social capital, as defined by Firth and colleagues as well as in this meta-analysis.

Another example of indications of social capital is established in a study done by Glover, Shinew, and Parry [81] that focus on how community gardeners use their social capital to access resources to forward the growth and development of their community gardens. The research is based on qualitative methodology, with in depth telephone interviews, focus group, and field interviews St. Louis, USA. Glover and colleagues states that "...garden leaders took advantage of their social status within the community by exploiting their social connections with people who did not belong to the community garden networks" [81, p 463].

An example of this is presented with a community gardener and activist using connections to further the interest of a community garden, and is quoted articulating that "I ... got to the point where I said "Wait a minute. Some of this stuff is specialized. Mr. Mayor, you're popular with these craftsmen around here. You know them like the back of your hand. A number of them are retired, aren't they?" He said "Oh, yeah." And I said, "How about giving me the names of some of them for when I run into a problem and can't take care of it." And so he gave me the names of people, and I called them and leaned on their faith and good will and I said, "we need your help" ...I had myself a whole team of electricians and carpenters" [81, p. 463]. Although how this 
relationship potentially is characterized by norms of respect and trust is not elaborated, it is an indication of linking social capital, where people who are interacting across explicit, formal or institutionalized power or authority gradients in society.

\section{Discussion}

As is presented in table 3 (above), specifically eight of the studies included exemplifies or substantiate (via quotes from interviews or quantitative data) that the studied community gardens create bonding social capital [2], [19], [56], [73], [77], [81], [82], [87], while three studies also emphasize that the bonding social capital created can have adverse effects [2], [56], [82]. These negative outcomes of bonding social capital concerns tensions between ethnic groups [56] an occurrence of social discrimination [82] and sanctions that can work as exclusion mechanisms as a result of differential access to social capital because of disadvantaged structural positions [2].

As regards to bridging social capital, eighteen articles included in this article exemplify or substantiate (via quotes from interviews or quantitative data) that the studied community gardens create bridging social capital [1], [2], [18], [19], [56], [64], [65], [68], [70-73], [76], [78], [81-84] while four studies show indications of linking social capital [1], [57], [81], [86]. There are numerous examples of studies claiming that social capital is produced in the studied urban community gardens, without substantiating this via examples from qualitative interviews or field studies or quantitative data, or stating that community gardens provide opportunities for creating social capital. However, as previously emphasized, stating that urban community gardens generate opportunities for producing social capital, is hardly surprising, as this is one of the definitional characteristics of urban community gardens; it is conceptually implied in the term 'community' in community gardening, that is, they involve convergence of individuals (members of a community) joining in garden activities. The community aspect of community gardens is precisely what distinguishes them from private gardens. Indeed, it is more fruitful and relevant to study how they create social capital, and the dimensions of social capital they create whether it being bonding, bridging, and/or linking.

It is obviously context-based whether and how urban community gardens create social capital, and urban community gardens. However, there is much to be learned from future research, informing whether and how urban community gardens can foster social capital, and thus benefit cities and local communities, in the age of the anthropocene, by using mixed methods approaches combining qualitative studies that focus on the meanings involved gardeners ascribe to their activities (and how the residents in the local neighborhoods perceive this) as well as documenting the sociodemographic, ethnic, and cultural composition of the volunteers and gardeners, for examples in comparison with the local neighborhood in general. This also implicates moving beyond only or primarily focusing on the cognitive dimension of social capital, and including the structural aspect of social capital, that is, by measuring the actual social networks established in the community gardens, quantitatively; the character of these, and the sociodemographic, ethnic, and cultural backgrounds of agents involved.

Another aspect of what we can learn from existing research on urban community gardens and social capital is engaging in the specific challenges and dimensions that current research identifies as important in the production of social capital in urban community gardens, which is also presented in overview in table 3 . These are for example to resolve potential language barriers experienced by migrant gardeners, if they are to be included [10], barriers to participation experienced by residents who lack fiscal resources and social connections [70], the importance of having an understanding of local cultural and societal features to encourage participation [12], and ensuring the gardens' can function as sanctuaries [67], and recreation space [64]. Furthermore it is emphasized how activities goes beyond the specific garden activities are important elements in creating social capital. For example, boundary activity, that is, interactions between external competences of individuals and socially defined competences in the gardens is important in engaging a greater amount and a wider diversity of people in its activities [88], vis-à-vis 'leisure episodes'; activities that are not specifically related to work-undertakings in the gardens, such as eating and drinking together are particularly important in building bridging social capital [70], [81]. Besides activities as important in building up social capital, so are facilities stressed as potentials barriers for inclusion, and accordingly, predominantly bridging social capital; the infrastructure of the garden and toilet facilities present, as these things are important in counteracting exclusionary mechanisms for especially disadvantaged citizens [67]. Additionally, particularly leadership, organized neighborhood activity, and recruitment activity are accentuated. Specific leadership activities that were reported as "key ingredients" in the gardens' success, includes promoting collective decision-making, communicating effectively, and promoting membership and belonging [19]. Likewise, organized activities such as community work days, yard and produce sales, harvest festivals for the entire neighborhood, and pumpkin carving contests, collaboration with local churches and organized youth job training programs can bolster social capital [19], [70], [72] capital, according to studies included in this meta-analysis. This may seem exceptionally general points, and as previously noted, urban community gardens are indeed embedded in different situational contexts. Nonetheless, including different specific barriers and potentials of community gardens' abilities to foster social capital, moves beyond just asking whether or not urban 
community gardens create social capital, and additionally asking the question, what are important elements or dynamics in creating social capital in community gardens. Furthermore, future research could establish valuable insights of social potentials of urban community gardens, by including measurement of social capital before and after the actual establishment of the garden, to gain a clearer picture of the causal effects of the gardens and the joined activities.

\section{Conclusion, Future Research and Limitations}

I have focused on answering two research questions in this meta-analysis: (1) How is it supported that urban community gardening creates or facilitates social capital, and (2) What can we learn from existing research on urban community gardens and social capital, analyzing the peer reviewed literature published from 2000 to 2016.

It is problematized that some studies claim that social capital is produced in the studied urban community gardens, without substantiating this via examples from qualitative interviews or field studies or quantitative data, or stating that community gardens provide opportunities for creating social capital. As this is one of the definitional characteristics of urban community gardens, this does not add anything to our understanding of social advantages of urban community gardens. Nonetheless it is confirmed that several of the studies in the meta-analysis demonstrate that urban community gardens indeed create social capital, both bonding, bridging, and - indications of - linking.

More specifically, eight studies in the meta-analysis exemplifies or substantiate (via quotes from interviews, field observations or quantitative data) that the studied community gardens construct bonding social capital, while three studies also emphasize that the bonding social capital created can have adverse effects. Eighteen articles analyzed demonstrate that the studied communities gardens create bridging social and only four studies indicate that urban community gardening generate linking social capital. Furthermore, the meta-analysis has identified several barriers and potentials concerning community garden's capacity to create social capital. Specifically emphasized here are the gardens' infrastructure and facilities, boundary activity, leisure episodes, overcoming potential language barriers and cultural understanding, leadership, organized neighborhood activity, recruitment activity, promoting collective decision-making, communicating effectively, and promoting membership and belonging, common work days, yard and produce sales, as well as harvest festivals for the entire neighborhood.

As a vast majority of studies are qualitative, future research can gain valuable insights, utilizing a mixed methods approach, combining qualitative studies that focus on the meanings involved ascribe to their activities, as well as map out and survey who in fact is involved in the gardens.
This research could map out the sociodemographic, ethnic, generational, and cultural composition of the volunteers and gardeners, for example in comparison with the local neighborhood in general. This also involves more focus on the structural dimensions of social capital, in addition to the cognitive dimensions. Moreover, future research could provide valuable insights concerning the specific effects of the community gardens (and related activities), by including measurement of social capital before and after the actual establishment of the garden, and enlightening the causal effects of the garden and the joined activities, just as there seemingly is a research gap regarding studies demonstrating how the gardens potentially can create linking social capital.

There are some apparent limitations in this meta-analysis. As the analysis only includes studies explicitly studying urban community gardens, and there is not definitional consensus of the concept, studies for example using the terms urban agriculture or urban farming (without also using the term community gardens), are not included. Furthermore, as only studies that explicitly focus on social dimensions and effects of community gardens are included, it is most likely that there are additional studies that involves interesting results regarding urban community gardens' impact on social capital.

\section{Acknowledgements}

I would like to thank reviewers, Paul Travis Brimhall, Karen-Lise Gram, Søren Lindbo, and Kurt Allenberg for helpful suggestions.

\section{REFERENCES}

[1] C. Firth, D. Maye, and D. Pearson, "Developing 'community' in community gardens," Local Environ., vol. 16, no. 6, pp. 555-568, 2011.

[2] T. D. Glover, "Social Capital in the Lived Experiences of Community Gardeners," Leis. Sci., vol. 40026, no. 2, pp. 143$162,2004$.

[3] T. D. Glover, D. C. Parry, and K. J. Shinew, "Building Relationships , Accessing Resources: Mobilizing Social Capital in Community Garden Contexts," J. Leis. Res., vol. 37, 4, pp. 450-474, 2005.

[4] J. "Yotti" Kingsley and M. Townsend, “Dig In' to Social Capital: Community Gardens as Mechanisms for Growing Urban Social Connectedness," Urban Policy Res., vol. 24, no. 4, pp. 525-537, 2006.

[5] P. Bendt, S. Barthel, and J. Colding, "Civic greening and environmental learning in public-access community gardens in Berlin," Landsc. Urban Plan., vol. 109, no. 1, pp. 18-30, 2013.

[6] M. L. Ohmer, "Citizen Participation in Neighborhood Organizations and Its Relationship to VOlunteers' Slef and 
Collective Efficacy and Sense of Community," Soc. Work Res., vol. 31, no. 7, pp. 109-121, 2007.

[7] L. Saldivar-Tanaka, "Culturing neighborhood open space, civic agriculture, and community development: the case of latino community gardens in New York City," Agric. Human Values, vol. 21, pp. 399-412, 2004.

[8] D. Armstrong, “A survey of community gardens in upstate New York: Implications for health promotion and community development," Health Place, vol. 6, no. 4, pp. 319-327, 2000.

[9] W. M. and B. M. Hlubik WT, Hamm MW, "Incorporating research with commu- nity gardens: The New Brunswick Community Gardening and Nutrition Program," in The Healing Dimensions of People-Plant Relations: Proceedings of a Research Symposium, L. P. and R. J. Francis M, Ed. UC Davis, CA: Center for Design Research, Department of Environmental Design, 1994, pp. 59-64.

[10] I. Agustina and R. Beilin, "Community Gardens: Space for Interactions and Adaptations," Procedia-Soc. Behav. Sci., vol. 36, pp. 439-448, 2012.

[11] T. D. Glover, K. Shinew, and D. Parry, "Association, sociability, and civic culture: The democratic effect of community gardening," Leis. Sci., vol. 27, no. 1, pp. 75-92, 2005 .

[12] L. Holland, "Diversity and connections in community gardens: a contribution to local sustainability.," Local Environ. Int. J. Justice Sustain., vol. 9, no. 3, pp. 285-305, 2004.

[13] C. Levkoe, "Learning democracy through food justice movements," Agric. Human Values, vol. 23, pp. 89-98, 2006.

[14] M. Elings, "People-Plant Interaction," in Farming for Health: Green-Care Farming Accross Europe and the United States of America, 2006, pp. 43-55.

[15] N. Comstock et al., "Neighborhood attachment and its correlates: Exploring neighborhood conditions, collective efficacy, and gardening," J. Environ. Psychol., vol. 30, no. 4, pp. $435-442,2010$.

[16] I. Middle, P. Dzidic, A. Buckley, D. Bennett, M. Tye, and R. Jones, "Integrating community gardens into public parks: An innovative approach for providing ecosystem services in urban areas," Urban For. Urban Green., vol. 13, no. 4, pp. 638-645, 2014.

[17] D. Guitart, C. Pickering, and J. Byrne, "Past results and future directions in urban community gardens research," Urban For. Urban Green., vol. 11, no. 4, pp. 364-373, 2012.

[18] J. Kimberly, D. Troy, C. Diana, K. J. Shinew, T. D. Glover, and D. C. Parry, "Leisure Spaces as Potential Sites for Interracial Interaction: Community Gardens in Urban Areas," J. Leis. Res., vol. 36, no. 3, pp. 336-355, 2004.

[19] E. Teig, J. Amulya, L. Bardwell, M. Buchenau, J. A. Marshall, and J. S. Litt, "Collective efficacy in Denver, Colorado: Strengthening neighborhoods and health through community gardens," Heal. Place, vol. 15, no. 4, pp. 1115-1122, 2009.

[20] C. Draper and D. Freedman, "Review and Analysis of the Benefits, Purposes, and Motivations Associated with Community Gardening in the United States," J. Community Pract., vol. 18, no. 4, pp. 458-492, 2010.

[21] A. Portes, "Downsides of social capital," Proc. Natl. Acad. Sci., vol. 111 , no. 52, pp. 18407-18408, 2014.

[22] S. Szreter and M. Woolcock, "Health by association? Social capital, social theory, and the political economy of public health," International Journal of Epidemiology, vol. 33, no. 4. pp. 650-667, 2004

[23] D. P. Keating, "Formative evaluation of the Early Development Instrument: Progress and prospects.," Early Education and Development, vol. 18, no. 3. pp. 561-570, 2007.

[24] I. Kawachi and L. F. Berkman, "Social Ties and Mental Health," J. Urban Heal. Bulliten New York Acad. Med., vol. 78, no. 3, pp. 458-467, 2001.

[25] J. Hagen, H. Merkens, and K. Boehnke, "Delinquency and Disdain: Social Capital and the Control of Right-Wing Extremism among East and West Berlin Youth," Am. J. Sociol., vol. 100, pp. 1131-56, 1995.

[26] F. Sampson, Robert J, Morenoff, Jeffrey D., Earls, "Beyond Social Capital: Spatial Dynamics of Collective Efficacy for Children," Am. Sociol. Rev., vol. 64, no. 5, pp. 633-660, 1999.

[27] I. Kawachi and D. Prothrow-Stith, "Social capital , income inequality, and mortality," Am. J. Public Health, vol. 87, no. 9 , pp. 1491-1498, 1997.

[28] N. Lin, X. Ye, and W. M. Ensel, "Social Support and Depressed Mood: A Structural Analysis," J. Health Soc. Behav., vol. 40, no. 4, pp. 344-359, 1999.

[29] B. W. Penninx, T. T. van, D. M. Kriegsman, A. J. Boeke, D. J. Deeg, and J. T. van Eijk, "Social network, social support, and loneliness in older persons with different chronic diseases," $J$. Aging Health, vol. 11, no. 2, pp. 151-168, 1999.

[30] B. Sévigny, J. Bélanger, R. Sullivan, B. Sévigny, and J. Bélanger, "Le capital social et 1 â€ $€^{\mathrm{TM}}$ amél santé et du bien-être des," vol. 90, no. 6, pp. 369-371, 1999.

[31] D. Raphael, R. Renwick, I. Brown, B. Steinmetz, H. Sehdev, and S. Phillips, "Making the links between community structure and individual well-being: Community quality of life in Riverdale, Toronto, Canada," Heal. Place, vol. 7, no. 3, pp. 179-196, 2001.

[32] S. V. Subramanian, I. Kawachi, and B. P. Kennedy, "Does the state you live in make a difference? Multilevel analysis of self-rated health in the US," Soc. Sci. Med., vol. 53, no. 1, pp. 9-19, 2001.

[33] I. Kawachi Kennedy B. P., \& Glass R., "Social capital and self-rated health: A contextual analysis," Am. J. Public Health, vol. 89, pp. 1187-1193, 1999.

[34] D. Halpern, Social Capital. Cambridge: Polity Press, 2004.

[35] M. Woolcock, "Social Capital and Economic Development: Toward a Theoretical Synthesis and Policy Framework," Theory Soc., vol. 27, no. 2, pp. 151-208, 1998.

[36] R. D. Putnam, Bowling Alone: The Collapse and Revival of American Community: New York: Simon und Schuster, 2001. $I S B N$, vol. 20. 2000.

[37] S. Arai and A. Pedlar, "Moving beyond individualism in leisure theory: a critical analysis of concepts of community and social engagement Moving beyond individualism in leisure theory: a critical analysis of concepts of community 
and social engagement," vol. 4367, no. March, 2017.

[38] J. Laurence, "The efficacy of neighborhood attitudes as measured of social capital: returning to norms and values and the centrality of networks," in Handbook of Research Methods and Applications in Social Capital, Y. Li, Ed. Cheltenham: Edward Elgar, 2015, pp. 145-165.

[39] L. Rocco and M. Suhrcke, "Is social capital good for health? A European perspective,” Euro.Who.Int, pp. 1-24, 2012.

[40] R. D. Putnam, "Bowling alone: Americas's declining social capital,” J. Democr., vol. 6, pp. 65-78, 1995.

[41] R. Putnam, "Robert Putnam responds," Am. Prospect, 1996.

[42] P. Bourdieu, "The forms of capital," in The handbook of theory and research for the sociology of education, J. G. Richardson, Ed. New York: Greenwood Press, 1986, pp. 241-258.

[43] J. S. Coleman, "Social capital in the creation of human capital," Am. J. Sociol., vol. 94, pp. 95-120, 1988.

[44] F. E. Baum and A.M. Ziersch, "Social capital," J. Epidemiol. Community Heal., vol. 57, pp. 320-323, 2003.

[45] N. Letki, "Does Diversity Erode Social Cohesion? Social Capital and Race in British Neighbourhoods," Polit. Stud., vol. 56, pp. 99-126, 2008.

[46] P. Paxton, "Is Social Capital Declining in the United States? A Multiple Indicator Assessment," Am. J. Sociol., vol. 105, no. 1, pp. 88-127, 1999.

[47] E. Villalonga-Olives and I. Kawachi, "The measurement of bridging social capital in population health research," Heal. Place, vol. 36, pp. 47-56, 2015.

[48] Y. Li, "Social capital in sociological research: conceptual rigour and empirical application," in Handbook of Research Methods and Applications in Social Capital, Yaojun Li, Ed. Cheltenham: Edward Elgar, 2015, pp. 1-21.

[49] M. Ernwein, "Framing urban gardening and agriculture: On space, scale and the public," Geoforum, vol. 56, no. September 2014, pp. 77-86, 2014.

[50] J. Salomon Cavin, "Entre ville sterile et ville fertile, l'emergence de l'agriculture urbaine en Suisse," Urban Environ., vol. 6, p. 15, 2012.

[51] P. Donadieu and A. Fleury, "L'agriculture, une nature pour la ville?," La Rech. Urbaine, vol. 74, pp. 31-39, 1995.

[52] M. B. Pudup, "It takes a garden: Cultivating citizen-subjects in organized garden projects," Geoforum, vol. 39, no. 3, pp. 1228-1240, 2008.

[53] N. Dempsey, G. Bramley, S. Power, and C. Brown, "The Social Dimension of Sustainable Development: Defi ning Urban Social Sustainability," Sustain. Dev., vol. 19, no. May 2009, pp. 289-300, 2011.

[54] J. Bircher, "Towards a dynamic definition of health and disease," Med. Heal. Care Philos., vol. 8, no. 3, pp. 335-341, 2005.

[55] K. Alaimo, T. M. Reischl, and J. O. Allen, "Community gardening, neighborhood meetings, and social capital," $J$. Community Psychol., vol. 38, no. 4, pp. 515-531, 2010.

[56] L. E. Baker, "Tending cultural landscapes and food citizenship in Toronto's community gardens," Geogr. Rev., vol. 94, no. 3 , pp. 305-325, Jul. 2004.

[57] L. Drake and L. J. Lawson, "Results of a US and Canada community garden survey: shared challenges in garden management amid diverse geographical and organizational contexts," Agric. Human Values, vol. 32, no. 2, pp. 241-254, Jun. 2015.

[58] R. Ghose and M. Pettygrove, "Actors and networks in urban community garden development," Geoforum, vol. 53, pp. 93103,2014

[59] J. Chan, B. DuBois, and K. G. Tidball, "Refuges of local resilience: Community gardens in post-Sandy New York City," Urban For. Urban Green., vol. 14, no. 3, pp. 625-635, 2015.

[60] I. Agustina et al., "The Community Garden as a Tool for Community Empowerment: A Study of Community Gardens in Hampden County," 2015.

[61] T. Macias, "Working toward a just, equitable, and local food system: The social impact of community-based agriculture," Soc. Sci. Q., vol. 89, no. 5, pp. 1086-1101, Dec. 2008.

[62] G. Martin, R. Clift, and I. Christie, "Urban Cultivation and Its Contributions to Sustainability: Nibbles of Food but Oodles of Social Capital," SUSTAINABILITY, vol. 8, no. 5, 2016.

[63] A. K. Hanna and P. Oh, "Rethinking Urban Poverty: A Look at Community Gardens," Bull. Sci. Technol. Soc., vol. 20, no. 3, pp. 207-216, 2000.

[64] M. L. Ohmer, P. Meadowcroft, K. Freed, and E. Lewis, "Community Gardening and Community Development: Individual, Social and Community Benefits of a Community Conservation Program," J. Community Pract., vol. 17, no. 4, pp. 377-399, 2009.

[65] S. Wakefield, F. Yeudall, C. Taron, J. Reynolds, and A. Skinner, "Growing urban health: Community gardening in South-East Toronto," Health Promot. Int., vol. 22, no. 2, pp. 92-101, 2007.

[66] K. Foo, D. Martin, C. Wool, and C. Polsky, "The production of urban vacant land: Relational placemaking in Boston, MA neighborhoods," Cities, vol. 35, pp. 156-163, 2013.

[67] J. "Yotti" Kingsley, M. Townsend, and C. Henderson Wilson, "Cultivating health and wellbeing: members' perceptions of the health benefits of a Port Melbourne community garden," Leis. Stud., vol. 28, no. 2, pp. 207-219, 2009 .

[68] H. McMillen, L. K. Campbell, E. S. Svendsen, and R. Reynolds, "Recognizing Stewardship Practices as Indicators of Social Resilience: In Living Memorials and in a Community Garden," SUSTAINABILITY, vol. 8, no. 8, Aug. 2016.

[69] A. Flachs, "Food for thought: The social impact of community gardens in the greater Cleveland area," Electron. Green J., no. $30,2010$.

[70] R. Ghose and M. Pettygrove, "Urban Community Gardens as Spaces of Citizenship," Antipode, vol. 46, no. 4, pp. 10921112, 2014.

[71] J. Hale et al., "Connecting food environments and health through the relational nature of aesthetics: Gaining insight through the community gardening experience," Soc. Sci. Med., vol. 72, no. 11, pp. 1853-1863, 2011. 
[72] K. A. Hartwig and M. Mason, "Community Gardens for Refugee and Immigrant Communities as a Means of Health Promotion," J. Community Health, vol. 41, no. 6, pp. 1153 1159, Dec. 2016.

[73] J. Ober Allen, K. Alaimo, D. Elam, and E. Perry, "Growing vegetables and values: benefits of neighborhood-based community gardens for youth development and nutrition," $J$. Hunger Environ. Nutr., vol. 3, no. 4, pp. 418-439, 2008.

[74] K. J. Shinew, T. D. Glover, and D. C. Parry, "Leisure Spaces as Potential Sites for Interracial Interaction: Community Gardens in Urban Areas," J. Leis. Res., vol. 36, no. 3, pp. 336355,2004

[75] D. H. Pearson and C. Firth, "Diversity in community gardens: Evidence from one region in the United Kingdom," Biol. Agric. Hortic., vol. 28, no. 3, pp. 147-155, 2012.

[76] M. Rosol, "Public Participation in post-fordist urban green space governance: The case of community gardens in Berlin," Int. J. Urban Reg. Res., vol. 34, no. 3, pp. 548-563, 2010.

[77] L. Slavuj Borčić, M. Cvitanović, and A. Lukić, “Cultivating alternative spaces - Zagreb's community gardens in transition: From socialist to post-socialist perspective," Geoforum, vol. 77, pp. 51-60, 2016.

[78] H. Shan and P. Walter, "Growing Everyday Multiculturalism: Practice-Based Learning of Chinese Immigrants Through Community Gardens in Canada ," Adult Educ. Q. , vol. 65, no. 1, pp. 19-34, 2015.

[79] N. Harris, F. R. Minniss, and S. Somerset, "Refugees connecting with a new country through community food gardening," Int. J. Environ. Res. Public Health, vol. 11, no. 9, pp. 9202-9216, 2014.

[80] T. D. Glover, "Social Capital in the Lived Experiences of Community Gardeners," Leis. Sci., vol. 40026, no. 2, pp. 143 162,2004
[81] T. D. Glover, D. C. Parry, and K. J. Shinew, "Building relationships, accessing resources: Mobilizing social capital in community garden contexts," J. Leis. Res., vol. 37, no. 4, pp. $450-474,2005$.

[82] J. Kingsley and M. Townsend, “'Dig In' to Social Capital: Community Gardens as Mechanisms for Growing Urban Social Connectedness," Urban Policy Res., vol. 24, no. 4, pp. 525-537, 2006.

[83] L. Saldivar-Tanaka and M. E. Krasny, "Culturing community development, neighborhood open space, and civic agriculture: The case of Latino community gardens in New York City," Agric. Human Values, vol. 21, no. 4, pp. 399-412, 2004.

[84] E. J. Veen, B. B. Bock, W. den Berg, A. J. Visser, and J. S. C. Wiskerke, "Community gardening and social cohesion: different designs, different motivations," LOCAL Environ., vol. 21, no. 10, pp. 1271-1287, 2016.

[85] Saguaro Seminar, "Social Capital Community Benchmark Survey.," in Cambridge, MA: John F. Kennedy School of Government, Harvard University., 2001.

[86] R. Ghose and M. Pettygrove, "Actors and networks in urban community garden development," Geoforum, vol. 53, pp. 93$103,2014$.

[87] J. Chan, B. DuBois, and K. G. Tidball, "Refuges of local resilience: Community gardens in post-Sandy New York City,' Urban For. Urban Green., vol. 14, no. 3, pp. 625-635, 2015.

[88] P. Bendt, S. Barthel, and J. Colding, "Civic greening and environmental learning in public-access community gardens in Berlin," Landsc. Urban Plan., vol. 109, no. 1, pp. 18-30, 2013.

[89] A. Dobson, Green Political Thought, no. 1995. London: Routledge, 2001. 